\title{
Üniversite Öğrencilerinde Tükenmişlik ve Yaşam Tatmini: KSÜ Öğrencileri Üzerine bir Çalışma
}

\author{
Mustafa MACIT*
}

öz

Toplumun bütün kesimleri gibi üniversite öğrencileri de tükenmişlik problemine maruz kalmaktadırlar. Bu çalışmanın amacı üniversite öğrencilerinin tükenmişlik ve yaşam tatmin düzeylerini ve aralarındaki ilişkiyi ortaya koymaktır. Kesitsel olarak tasarlanan bu çalışmaya 475 üniversite öğrencisi katkıda bulunmuşlardır. Analizler ögrencilerin tükenmişlik algılarının yüksek buna karşın yaşam tatmin düzeylerinin düşük olduğunu göstermektedir. Çalışmanın temel bulgusu öğrencilerin tükenme ve duyarsızlaşma algılarının yaşam tatmini ile negatif yönlü anlamlı, buna karşın yetkinlik algılarının yaşam tatmini ile pozitif yönlü olduğu ilişkisidir. Ayrıca son sınıf öğrencilerinin algıladıkları tükenmişlik düzeyinin yüksekliği, yine anne ve babanın eğitim düzeylerinin yükselmesi ile yaşam tatminin olumlu etkilendiği diğer önemli bir bulgular arasındadır. Sonuçlar literatür bağlamında yorumlanmış ve araştırmanın kısıtları ve önerilere değinilerek çalışma sonuçlandırılmıştır.

Anahtar Kelimeler: Tükenmişlik, Yaşam Tatmini, Üniversite Öğrencileri

JEL Sinıflandırması: I31, A22, Z39

\section{Burnout and Life Satisfaction Amongst University Students: A Study on KSU Students}

\begin{abstract}
Like all segments of the society, university students are also exposed to the problem of burnout. The aim of this study is to explain the burnout and life satisfaction levels of university students and the relationship between them. 475 students contributed to this cross-sectional study. Analyses resulted that students' perceptions of burnout were high whereas their life satisfaction levels were low. The main finding of the study is that students' perceptions of burnout and depersonalization are negatively and significantly related with life satisfaction, whereas their self-efficacy perceptions are positively associated with life satisfaction. The high level of burnout perceived by senior students and increase of life satisfaction of the students via the rise of the education levels of their parents were another important result. The results were interpreted in terms of the literature and the study was concluded by referring to the limitations and recommendations of the research.
\end{abstract}

Keywords: Burnout, Life Satisfaction, University Students

JEL Classification: I31, A22, Z39

\footnotetext{
* Dr. Öğr. Üyesi, Kahramanmaraş Sütçü İmam Üniversitesi, İİBF, Sağlık Yönetimi Bölümü, msmacit@ gmail.com, ORCID: 0000-0002-5672-5161.
} 


\section{GİRIŞ}

Yirminci yüzyılın insanlara getirdiği sorunlar arasında özel bir önem arz eden konuların başında tükenmişlik gelmektedir (Maslach, Schaufeli ve Leiter 2001:398). Kavramın kaynaklarda ilk defa kullanılışı Shakespeare'a kadar uzanmakta olup, 20. yüzyılda ise ilk kez H.B. Bradley (1969) tarafından genç suçlulara gözetmenlik yapan çalışanlar hakkında yazılan bir makalede kullanılırken (Schaufeli ve Buunk, 2003:383), özellikle öğretmenler, hemşireler, sosyal hizmet çalışanları gibi meslekleri etkileyen tükenmişliğin akademik anlamda ilk kullanımını 1973 yılında H. J. Freudenberger tarafindan yapılmış ve bu tarihten sonra ise, hem yazında hem de günlük yaşamda oldukça sık kullanılan kavramlardan birisi haline gelmiştir (Freudenberger, 1989:1). Tükenme, sinizm ve performans düşüklüğü şeklinde üç boyutu olan ve duygusal ve kişilerarası uyarıcılara verilen uzun süreli tepki olarak tanımlanan tükenmişlik (Maslach, Schaufeli ve Leiter, 2001:397) ilk zamanlar daha çok sağlık ve sosyal hizmetler, psikoterapi, adalet hizmetleri ve polislik gibi insanlarla yüz yüze çalışmak durumunda kalınan mesleklere özgü olarak düşünülse de sonraları bütün çalışma alanlarında hatta çalışma alanı dışında da olsa insanların önemli bir kısmında varlığı iddia edilen bir fenomen haline gelmiştir (Schaufeli, Leiter ve Maslach, 2009:204-206). Öğrencilerin yaşadığ1 tükenmişlik ise özellikle 1980'li yıllardan itibaren yazında ilgi çekmeye başlamıştır (Balogun, Hoeberlein-Miller, Schneider ve Katz, 1996:21; Schaufeli, Martinez, Pinto, Salanova ve Bakker, 2002:464; Kiuru, Aunola, Nurmi, Leskinen ve Salmela-Aro, 2008:25; Salanova, Schaufeli, Martínez ve Bresó, 2010:54). Ülkemizde ise konuya asıl ilgi 2010'lu yıllardan sonrasındadır (Çapri, Gündüz and Gökçakan, 2011:134; Aypay, 2011:511; Seçer, Halmatov, Veyis ve Ateş, 2013:16).

Öğrenciler istihdam ediliyor olmamalarına ve bir görev üstlenmemelerine karşın psikolojik bağlamda düşünüldügünde öğrenciliğin temel faaliyetleri bir iş olarak değerlendirilebilir. Öğrencilik derslere katılmak ve ödevleri yapmak gibi yapılandırılmış ve zorunlu temel faaliyetlerin yanında, sınavlarda başarılı olmak ve belirli bir diplomayı elde etmek gibi belirlenmiş amaçlara ulaşmayı gerektirmektedir. Bunun yanında az da olsa bazı öğrencilerin üniversite yaşamı ile iş yaşamını bir arada sürdürebileceği de dikkate alındığında tükenmişlik öğrenciler arasında yadsınamayacak bir şekilde kendisini gösterebilir (Schaufeli, Martinez, Pinto, Salanova ve Bakker, 2002:464; Schaufeli ve Taris, 2005:260; Salmela-Aro, Kiuru, Leskinen ve Nurmi, 2009:48). Öğrencilerde tükenmişliğin ortaya çıkma sebepleri olarak akademik anlamda çalışma yükleri ve çalışmaya karşı takınabilecekleri şüpheci ve kayıtsız tavirlar (Schaufeli ve Taris, 2005:260), okulla ilgili yetkinliklerinin azalmas1, kendini yetersiz görme say1labilir (Hernesniemi, Räty, Kasanen, Cheng, Hong ve Kuittinen, 2017:400). Eğitim hayatına ilişkin tükenmişlik çalışma taleplerinden (ödevler, proje hazırlıkları gibi) kaynaklanan tükenme, eğitim ile ilgili çalışmalara karşı şüpheci ve mesafeli tutum ve bir öğrenci olarak kendini yetersiz görme şeklinde görülmektedir (Kiuru, Aunola, Nurmi ve Salmela-Aro, 2008:25). Aslında üniversite eğitimi öğrenci bilfiil meşgul olmasa da insanı zihnen sürekli meşgul eden bir tarafı olmasından dolayı tükenmişlik açısından önemlidir. Çünkü iş veya eğitim gibi belirli konulara aşırı odaklanma tükenmişliği ortaya çıkarabilir (Law, 2007:240). Birçok öğrencinin ailesinden ilk defa ayrılmış olması, farklı bir çevre, hayatını sürdürme sorumluluğunun bir ölçüde kendi omuzlarına yüklenmiş olması (Tsitsas, Nanopoulos ve Paschali, 2019:948), belirsizliklerin çok fazla olduğu yeni bir yaşama hazırlanma kaygıları da (Seçer ve Yazıc1, 2018:49; Demir ve Taşkıran, 2018:48) öğrencilerin stres yaşamalarına bu da tükenmişliğe sebebiyet verebilir. Çünkü tükenme bireyin maruz kaldığı stres durumlarına karşı bir cevabıdır ve tükenmişliğin tükenme alt boyutu aslında stres boyutudur denilebilir (Maslach, Schaufeli ve Leiter, 2001:399).

Takip eden bölümde kavramsal çerçeve hakkında bilgi verildikten sonra ilgili değişkenler üzerinde yapılan araştırmalar yer verilecektir. Araştırmanın yöntemi, bulgular ve tartışma ve sonuç bölümleri ile çalışma tamamlanacaktır. 


\section{KAVRAMSAL ÇERÇEVE}

$\mathrm{Bu}$ bölümde çalışmanın temel değişkenleri olan tükenmişlik ve yaşam tatmini kavramları açıklanarak, ilgili değişkenler bağlamında yapılan çalışmalara değinilecektir.

\subsection{Tükenmişlik}

Tükenmiş̧lik üç boyutlu bir sendrom olup temel boyutu artan duygusal tükenmedir. Duygusal kaynaklarının tükendiğini hisseden çalışanlar artık psikolojik anlamda işlerine verebilecekleri bir şey kalmadığını düşünmeye başlamaktadırlar. İkinci boyut ise hizmet verdikleri insanlara karşı geliştirilen şüpheci tutumlardır. $\mathrm{Bu}$ tutum duygusal tükenme ile ilişkilidir. Bir nevi insanî olmayan bu algılama, hizmet alanların yaşadıklarını, başlarına gelenleri bir şekilde hak ettikleri düşüncesini doğurmaktadır. Üçüncü boyut ise kişinin işi ve hizmet verdikleri konusunda kendisini olumsuz olarak değerlendirmesi yani kendisi hakkında mutsuzluk duyarak, işi konusundaki performansını tatmin edici bulmamasıdır (Maslach ve Jackson, 1981:99). Tükenmişlik örgüt yaşamında hem performans hem de sağlik açısından olumsuz sonuçlarla ilişkilendirilmektedir. Performans açısından devamsızlık, işten ayrılma niyeti ve işten ayrılma sayılırken, tükenmişlik özellikle stresle ilişkili hastalıklarla bağlantılı bir tablo ortaya koymaktadır. Bunlar arasında ise madde bağımlılığı, anksiyete, depresyon özgüven kaybı ilk siralarda gelmektedir (Maslach, Schaufeli ve Leiter, 2001:406).

Araştırmalar öğrencilerin yaşadıkları tükenmişliğin bir halk sağlığı sorununa dönüştügünü ortaya koymaktadır. Çünkü tükenmişliğin artan endişe düzeyi, depresyon, riskli davranışlar (Shankland, Kotsou, Vallet, Bouteyre, Dantzer ve Leys, 2019:91), uykusuzluk, (üniversiteye) devamsızlık, alkol ve madde kullanımı ve öğrenimi bırakma (Hernesniemı vd., 2017:400) anksiyete ve depresyon gibi içselleştirilen problemler ile bedensel birtakım semptomlarla ilişkisi olduğu ve intihar fikrini düşündürdüğü ortaya konmuştur. Öğrenciler arasında okulla ilgili tükenmişlik konusunda bir inceleme çalışmasında birçok araştırmanın tükenmişliğin depresyon, hastalık belirtileri, özellikle okulu terk etme gibi akademik eğilimler ile sonuçları vurgulanırken, uyumsuzluk ve yüksek riskli davranışlarla ilgili sonuçlarının bilinmediğine de dikkat çekilmektedir (Walburg, 2014:30). Dyrbye, Thomas, Massie, Power, Eacker, Harper vd. (2008:340) yaptıkları çalışmada tıp öğrencilerinin yaşadıkları tükenmişliğin artışının intihar fikrini güçlendirdiği, tükenmişliğin azalmasının bu fikri azalttığı bulgusuna ulaşmışlardır.

\subsection{Yaşam Tatmini}

Yaşam tatmini bireylerin kendilerine özgü kriterler bağlamında yaşamları ile ilgili yargılarını ifade etmektedir. Kişiler algıladıkları yaşam koşullarını kendilerince belirledikleri standartlarla karşılaştırarak bu standartların ne ölçüde karşılandığını değerlendirirler. Eğer algıladıkları yaşam standartları belirledikleri standartların üzerinde ise yüksek yaşam tatmine sahip olduklarını ifade ederler. Dolayısıyla yaşam tatmini her bireyin kendisine özgü yaşam standartları hakkındaki bilişsel yargısıdır (Pavot ve Diener, 1993:164). Yaşam tatmini diğer bir ifade ile öznel gönenç hayatın tamamını dikkate aldığında kişinin hayatını nasıl değerlendiğini ifade etmektedir ve bireyin hayatının tamamıyla ilgili genel anlamda nasıl bir tepkisel değerlendirmeye sahip olduğunu ortaya çıkarmayı amaçlamaktadır. Yaşam, belirli bir zaman noktasında hayatın tüm alanlarını kapsayan bir kavram olarak tanımlanabilir (Diener, Oishi ve Lucas, 2003:404; Diener, 2006:154). Yaşam tatmini kişinin bilişsel ve genel anlamda yaşamının tamaminın kalitesinden tatminini ifade etmektedir (Diener, Emmons, Larsen ve Griffin, 1985:71). 
Öğrencilerin yaşam tatminini güçlendirmek aslında eğitimin temel misyonlarından birisidir (Chow, 2005:140). Yaşam tatmini, yaşamı uzatırken, örgütsel bağlılık, iş performans1 ve işi bırakma gibi yine örgütsel bazı pozitif sonuçlarla da ilişkilendirilmektedir (Hakanen ve Schaufeli, 2012:416). Bir milletin gelecekteki refahı öğrencilerin öznel gönencine bağlıdır denilebilir. Çünkü üniversite öğrencileri gelecekteki liderlik pozisyonlarının sahiplerini temsil etmektedirler. Dolayısıyla bütün ülkelerin geleceğe dönük en büyük yatırımları olduğu söylenebilir (Møller, 1996:16). Bu bağlamda öğrencilerin yaşam tatmin düzeylerinin de gelecek açısından bir takım olumlu ve olumsuz yansımalarının olacağı iddia edilebilir. Üniversite öğrencilerinin yaşam tatmin düzeyleri belirlenerek bu kapsamda bazı olumsuzluklar var ise bunun geleceğe olumsuz yansımaması adına zamanında birtakım girişimler yapılabilir.

Yerli yazında tükenmişlik konusunda farklı değişkenlerle yapılan araştırmaların sayısının çok olmasına karşın öğrencilerde tükenmişliği ve yaşam tatminini birlikte inceleyen çalışmaların az sayıda olduğu belirlenmiştir (Çağatay İn ve Şanlı Kula, 2019:411; Çapri, Özkendir, Özkurt ve Karakuş, 2012:968; Çapri, Gündüz ve Akbay, 2013:35; Pınar, Bilgiç, Demirel, Akyüz, Karatepe ve Sevim, 2015:284). Yazında tükenmişlik ve yaşam tatminini birlikte araştıran çalışmaların genellikle sağlık alanında eğitim gören üniversite öğrencileri bazında olduğu ve üniversitelerdeki farklı alanlarda eğitim gören öğrenciler kapsamında da araştırmaların yapılmasının bir ihtiyaç olduğu vurgusu yapılmaktadır (Robins, Roberts ve Sarrin, 2018:126). Ayrıca daha önceki araştırmalarda da yaşlılarla karşılaştırıldığında gençlerin ve eğitim düzeyi yüksek olanların daha fazla tükenmişlik yaşadıkları bulgusu söz konusudur (Maslach, Schaufeli ve Leiter, 2001:409-410). İş yaşamının bir adım öncesinde bulunan üniversite öğrencilerinin eğitim hayatında yaşadıkları tükenmişlik iş yaşamında artarak daha fazla tükenmişlik yaşamalarına yol açabilmektedir (Sevencan, Uzun, Yücel, Şener, Yılmaz ve Üner, 2011:43). Farkl1 coğrafyalarda (ABD, Brezilya, Kuzey ve Doğu Avrupa, Asya, Malezya, Avusturalya ve Türkiye) ve farklı düzeylerde eğitim gören öğrenciler arasında yapılan araştırmalar tükenmişliğin hemen hemen bütün ülkelerde varlığını göstermektedir (Çapri, Gündüz ve Gökçakan, 2011:134; Law, 2007:239; Walburg, 2014:30; Costa, Santos, Santos, Melo ve Andrade, 2012:573; Dyrbye, West, Satele, Boone, Tan, Sloan vd., 2014:443; Robins, Roberts, Sarris, 2018:115).

Yaşam tatmininin bütün insanların önde gelen arzuları arasında olduğu söylenebilir. Aslında yaşam tatmini bireyin yaşamının bulunduğu anında ve uzun bir geçmişi düşünerek yaptığı kişisel değerlendirme olarak düşünüldüğünde (Diener, Oishi ve Lucas, 2003:404) tükenmenin yaşam tatminini etkileyeceği beklenebilir. Çünkü önemli ölçüde strese maruz kalan, omuzlarına binen ağır yük ile duygusal ve fiziksel kaynaklarının tükendiğini, işin değişik yönlerine karşı olumsuz duygular geliştirdiğini, hislerinden yoksun kaldığını ve işinde yetkin olmadığını dolaysıyla verimli olamayacağını düşünen (Maslach, Schaufeli ve Leiter, 2001:399) bir bireyin yaşamı hakkında genel ve geçmişe dönük belli bir dönem için olumlu değerlendirmeler yapması zorlaşacaktır denilebilir. Konu hakkında verilen bu bilgiler ayrıca tükenmişlik ve yaşam tatmini arasındaki ilişkinin özellikle üniversite öğrencileri bağlamında çok fazla araştırılmamış olmasının bu konuda yapılacak bir araştırmayı ilginç kılacağı değerlendirilerek, böyle bir çalışmanın hem literatüre hem de uygulamaya katkıları olacağı değerlendirilmiştir.

\subsection{Konu Hakkında Yapılan Araştırmalar}

Çağatay İn ve Şanlı Kula (2019:411) bir üniversitenin farklı fakülte ve yüksekokullarının birinci ve dördüncü sınıfları kapsamında yaptıkları çalışmada duygusal tükenme ve duyarsızlaşma boyutları ile yaşam tatmini arasında negatif yönde zayıf, buna karşın yetkinlik ve yaşam tatmini arasında pozitif yönde düşük düzeyde istatistiksel olarak anlamlı ilişki tespit etmişlerdir. Çapri, Özkendir, Özkurt ve Karakuş (2012:970) üniversite öğrencilerinin 
örneklemi oluşturduğu bir çalışmada Maslach Tükenmişlik Envanteri-Öğrenci Formunun boyutlarından tükenme ve duyarsızlaşmanın yaşam tatmini ile negatif, yetkinlik boyutunun ise pozitif ilişkisi olduğu bulgusuna ulaşmışlardır. Pınar vd. (2015:284) tarafindan sağlık bilimleri alanlarında eğitim gören üniversite son sınıf öğrencilerinin katılımlarıyla yapılan çalışmada da tükenme, duyarsızlaşma ve yetkinlik boyutlarının yaşam tatmini ile negatif yönlü anlamlı ilişkileri olduğu belirlenmiştir. Yine Çapri, Gündüz ve Akbay'ın (2013:41) lise öğrencileri dahilinde yaptıkları çalışmada da tükenme, duyarsızlaşma ve yetkinliğin yaşam tatmini ile negatif ve anlamlı ilişkileri bulgulanmıştır. Vurgulamak gerekir ki yukarıda verilen araştırmalarda yetkinlik boyutu hakkındaki bulgular farklılık göstermektedir. Belirtilen ilk iki çalışmada yetkinlik boyutu ile yaşam tatmini arasında pozitif yönlü ilişki olmasına karşın takip eden iki çalışmada yetkinlik ile yaşam tatmini arasında negatif yönlü bir ilişkinin varlığı dikkat çekmektedir. Buna göre yetkinlik algısının artışı yaşam tatminini hem artırıcı hem de azaltıcı bir işlev görmektedir. Ancak okul idarecileri kapsamında tükenmişlik ve yaşam tatmini üzerine yapılan başka bir çalışmanın sonuçları da yukarıda verilen ilk iki çalışmanın sonuçları ile birebir örtüşmektedir. Karaköse, Kocabaş, Yirci, Esen ve Çelik (2016:1491) tarafindan yapılan bu çalışmada tükenme ve duyarsızlaşma ile yaşam tatmini arasında negatif yönlü bir ilişki söz konusu iken yetkinlik ile yaşam tatmini arasında ise pozitif yönlü bir ilişki belirlenmiştir. Yine Güney Kore'de eczacılık eğitimi gören üniversite öğrencilerinin katkı sağladığı bir araştırmada tükenme ve duyarsızlaşma boyutlarının yaşam tatmini ile negatif ilişkisi olduğu bulgusuna ulaşılmıştır. Ayrıca öğrencilerinin yaşadıkları tükenmişlik bilişsel ve davranışsal tepkilerini etkileyerek, motivasyon kaybına sebep vermekte ve uzun vadede depresyona yol açmaktadır (Cho ve Jeon, 2019:6-8). Çin'de tıp fakültesinde eğitim gören öğrencilerin algıladığı tükenmişliğin azalmasıyla yaşam tatmininin arttığı bulgusuna ulaşılmıştır (Wang, Wang, Shi, Li, Liu, Liu, vd., 2019:8).

Güney, Kalafat ve Boysan (2010:1210) üniversite öğrencileri arasında yaptıkları bir çalışmada yaşam tatmininin depresyon, anksiyete ve ümitsizlik ile negatif biçimde anlamlı ilişkisi olduğunu belirlemişlerdir. Wachholtz and Rogoff (2013:86) sağlık eğitimi gören öğrencilerle yaptıkları çalışmada algılanan tükenmişliğin yaşam tatmini ile negatif yönlü ilişki içerisinde olduğu bulgusuna ulaşmışlardır. Gorji, Teimuri, Gorji ve Gorji (2015:37) hemşirelik ve ebelik okuyan üniversite öğrencilerinin örneklemi oluşturduğu araştırmada da tükenmişlik ile yaşama tatmini arasında negatif yönlü ilişki olduğu bulgusuna ulaşmışlardır.

Öğrencilerin dışında da yaşanan tükenmişliğin yaşam tatminini olumsuz etkilediği yönünde çalışmalar bulunmaktadır. Demerouti, Bakker, Nachreiner ve Schaufeli (2000:461) hemşireler arasında tükenmişliğin yaşam tatminine etkisini inceledikleri araştırmada, tükenmişliğin yaşam tatminini azalttığ 1 belirlenmiştir. Hakanen ve Schaufeli (2012:421) tarafından Finlandiyalı diş hekimleri dahilinde yapılan boylamsal bir çalışmada tükenmişliğin depresyonun gelişiminde bir safha olduğu belirlenerek, tükenmişlikten korumak için yaşam tatminin artırılması gereğinin bir ihtiyaç olduğu bulgusuna ulaşılmıştır. Ayrıca iş yaşamındaki tatminin bireyin genel öznel tatmini, gönencini olumlu etkilediği belirlenmiştir. Bu çalışmaların sonuçları değerlendirildiğinde öğrencilikte yaşanılan tükenmişliğin bireyin genel yaşam tatmini olumsuz etkilemesi beklenebilir.

\section{YÖNTEM}

Kesitsel olarak tasarlanan bu çalışmanın temel amacı üniversite öğrencilerinin tükenmişlik ve yaşam tatmini düzeylerini tespit etmek ve tükenmişliğin yaşam tatmini ile ilişkisini ortaya koymaktır. Literatür taraması ve konu hakkında yapılan ve yukarıda değinilen araştırmalar doğrultusunda araştırmanın amacı için takip eden hipotezler geliştirilmiştir. 
H1: Katılımcı öğrencilerin algıladıkları tükenme düzeyi ile yaşam tatmini arasında negatif yönlü bir ilişki vardır.

H2: Katılımcı öğrencilerin algıladıkları duyarsızlaşma düzeyi ile yaşam tatminleri arasında negatif yönlü bir ilişki vardır.

H3: Katılımcı öğrencilerin algıladıkları yetkinlik düzeyleri ile yaşam tatminleri arasında pozitif yönlü bir ilişki vardır.

Ayrıca katılımcı öğrencilerin bazı demografik özellikleri ile bu araştırmada incelenen tükenme, duyarsızlaşma, yetkinlik ve yaşam tatmini gibi temel değişkenler arasındaki ilişkilerin belirlenmesi de bu araştırmanın ikincil amaçları arasındadır.

\subsection{Evren ve Örneklem}

Araştırmanın evrenini 2019-2020 eğitim öğretim döneminde Kahramanmaraş Sütçü İmam Üniversitesi İÏBF'nin farklı bölümlerinde kayıtlı 4435 öğrenci oluşturmaktadır. Bu bilgi KSÜ İ̈BF öğrenci işleri yetkililerinden alınmıştır. Buna göre $\% 5$ hata payı dikkate alındığında örneklem için 354 katılımcı yeterli olmasına karşın katılımcı sayısı 475 olarak gerçekleşmiştir. Araştırma için KSÜ Sosyal ve Beşerî Bilimler Etik Kurulundan 03/10/2019 tarih ve E.40523 sayılı yazı ile izin alınmıştır. Örneklem seçiminde kolayda örnekleme yöntemi tercih edilmiştir.

\subsection{Veri Toplama Araçları}

Veri toplamak amacıyla iki ölçek kullanılmıştır. Bunlar;

Maslach Tükenmişlik Envanteri-Öğrenci Formu: Maslach Tükenmişlik Ölçeği Schaufeli, Martinez, Pinto, Salanova ve Bakker (2002) tarafindan öğrenci formuna uyarlanmıştır. Bu ölçek Çapri, Gündüz ve Gökçakan (2011) tarafından Türkçe 'ye uyarlanmıştır ve tükenme (beş önerme), duyarsızlaşma (dört önerme) ve yetkinlik (dört önerme) olmak üzere üç alt boyuttan oluşmaktadır. Uyarlama çalışmasında ölçeğin Cronbach Alfa iç tutarlık katsayısı bu boyutlar için sırasıyla .76, .82, ve .61 olarak bulunurken, test-tekrar test güvenirlik sonuçları ise yine sirasıyla $.76, .74$ ve .70 olarak bulunmuştur. Bu bulgular ölçeğin geçerli ve güvenilir bir ölçme aracı olduğunu göstermektedir.

Yaşam Memnuniyeti Ölçeği: Diener, Emmons, Larsen ve Griffin (1985) tarafından geliştirilmiştir. Ölçek ilk defa Köker (1991:71) tarafından Türkçe 'ye uyarlanmıştır fakat ölçeğin güvenirlik katsayısının belirtmemesine karşın ölçeğin üç hafta arayla uygulanan test tekrar test tutarlılık katsayısının .85 olduğu belirlenmiştir. Yakın zamanlarda yapılan bir çalışmada da (Öztürk ve Ünal, 2019:66) aynı ölçeğin güvenirlik katsayısının .76 olduğu tespit edilmiştir. Her iki ölçeğin maddeleri "Kesinlikle Katılmıorum" seçeneğinden "Kesinlikle Katılıyorum" seçeneğine kadar 7'li Likert ölçeği ile derecelendirilmektedir. Bu iki ölçeğe ek olarak araştırmac1 tarafindan geliştirilen ve katılımcıların demografik özelliklerini belirlemeye yönelik on üç soru anket formuna ilave edilmiştir.

\subsection{Verilerin Analizi}

Örneklemin demografik özellikleri takip eden Tablo 1'de verilmiştir. 
Tablo 1: Örneklemin Demografik Özellikleri

\begin{tabular}{|c|c|c|c|c|}
\hline \multirow{3}{*}{ Cinsiyet } & & Sıklık & Yüzde & Toplam Yüzde \\
\hline & $\mathrm{K} 1 \mathrm{Z}$ & 273 & 57,5 & 57,5 \\
\hline & Erkek & 202 & 42,5 & 100,0 \\
\hline \multirow[t]{2}{*}{ Yaş } & 18 ila 20 & 228 & 48,0 & 48,0 \\
\hline & 21 ve üzeri & 247 & 52,0 & 100,0 \\
\hline \multirow[t]{6}{*}{ Bölüm } & Sağlık yönetimi & 161 & 33,9 & 33,9 \\
\hline & İktisat & 34 & 7,2 & 41,1 \\
\hline & İşletme & 60 & 12,6 & 53,7 \\
\hline & Kamu Yönetimi & 162 & 34,1 & 91,2 \\
\hline & Uluslararas1 Ticaret ve Lojistik & 42 & 8,8 & 100,0 \\
\hline & Sosyal hizmet & 16 & 3,4 & 57,1 \\
\hline \multirow[t]{5}{*}{ Anne eğitim } & Okur yazar değil & 73 & 15,4 & 15,4 \\
\hline & İlköğretim & 288 & 60,6 & 76,0 \\
\hline & Lise & 73 & 15,4 & 91,4 \\
\hline & Yüksekokul & 11 & 2,3 & 93,7 \\
\hline & Üniversite & 30 & 6,3 & 100,0 \\
\hline \multirow[t]{5}{*}{ Baba eğitim } & Okur yazar değil & 12 & 2,5 & 2,5 \\
\hline & İlköğretim & 273 & 57,5 & 60,0 \\
\hline & Lise & 116 & 24,4 & 84,4 \\
\hline & Ön Lisans & 23 & 4,8 & 89,3 \\
\hline & Lisans & 51 & 10,7 & 100,0 \\
\hline \multirow[t]{3}{*}{ Aile gelir } & Düşük & 53 & 11,2 & 11,2 \\
\hline & Orta & 374 & 78,7 & 89,9 \\
\hline & Yüksek & 48 & 10,1 & 100,0 \\
\hline \multirow{4}{*}{ Okuduğu sınıf } & 1.sinif & 55 & 11,6 & 11,6 \\
\hline & 2.sinif & 189 & 39,8 & 51,4 \\
\hline & 3.sinif & 153 & 32,2 & 83,6 \\
\hline & 4.sinif & 78 & 16,4 & 100,0 \\
\hline \multirow[t]{5}{*}{ Mezun olduğu okul } & Fen lisesi & 12 & 2,5 & 2,5 \\
\hline & Anadolu öğretmen lisesi & 21 & 4,4 & 6,9 \\
\hline & Anadolu lisesi & 259 & 54,5 & 61,5 \\
\hline & Meslek lisesi & 90 & 18,9 & 80,4 \\
\hline & Genel lise & 93 & 19,6 & 100,0 \\
\hline \multirow[t]{4}{*}{ Kardeş sayısı } & Bir & 42 & 8,8 & 8,8 \\
\hline & İki & 92 & 19,4 & 28,2 \\
\hline & Üç & 111 & 23,4 & 51,6 \\
\hline & Dört & 230 & 48,4 & 100,0 \\
\hline \multirow[t]{4}{*}{ Kaldığı yer } & Yurtta & 213 & 44,8 & 44,8 \\
\hline & Evde (tek başıma) & 31 & 6,5 & 51,4 \\
\hline & Evde (arkadaşlarla) & 77 & 16,2 & 67,6 \\
\hline & Ailemin yanında & 154 & 32,4 & 100,0 \\
\hline \multirow[t]{2}{*}{ Aile türü } & Çekirdek aile & 345 & 72,6 & 72,6 \\
\hline & Geniş aile & 130 & 27,4 & 100,0 \\
\hline \multirow[t]{2}{*}{ Bölümü önerme } & Evet & 175 & 36,8 & 36,8 \\
\hline & Hayır & 300 & 63,2 & 100,0 \\
\hline \multirow[t]{3}{*}{ Bölümü seçme } & İsteyerek & 287 & 60,4 & 60,4 \\
\hline & İsteksiz & 188 & 39,6 & 100,0 \\
\hline & Toplam & 475 & 100,0 & \\
\hline
\end{tabular}

Araştırmaya Kahramanmaraş Sütçü İmam Üniversitesi İktisadi ve İdari Bilimler Fakültesinin değişik bölümlerinde okuyan öğrenciler gönüllü olarak katılmışlardır. Ölçekler ve demografik sorulardan oluşan anket formu yazılı olarak gönüllü öğrencilere verilerek, cevaplamaları sağlanmıştır. Bunun sonucunda 475 adet katılım sağlanmış olup, SPSS programına aktarılarak, veri setine dönüştürülmüştür (Eren, 2018). Öğrencilerin 273'ü $(\% 57,5)$ kız, 202'si $(\% 42,5)$ erkektir. Örneklemin demografik özellikleri Tablo 1'de verilmiştir. 
Katılımcıların çoğunluğunu kız öğrenciler oluştururken \%57,5 (n=273), öğrencilerin ailelerinin büyük kısmı orta gelir düzeyinde \%78,7 $(n=374)$, çoğunluk bölümü \%60,4 $(n=287)$ isteyerek seçmiş olmasına rağmen bölümü önerme oranlarının \%36,8 (n=175) olduğu görülmektedir. Her ne kadar bölümü isteyerek seçme oranı yüksek görünse de bu oran ihtiyatla değerlendirilmelidir. Türkiye'deki eğitim sistemine özgü nedenlerden dolayı birçok öğrenci üniversite okuyabilmek için istemedikleri bölümleri de tercih etmek zorunda kalabilmektedirler (Gündoğar, Gül, Uskun, Demirci ve Keçeci, 2007:14). Bölümü başkalarına tavsiye etme oranın düşük olması az önceki iddiaya kuvvet kazandırdığı gibi, öğrencilerin eğitim başladıktan sonra bölüm ile ilgili bekledikleri kazanımların karşılanmadığı düşüncesi de değerlendirilmelidir. Ölçekler ve alt boyutları için yapılan güvenirlik testi sonuçları Tablo 2'de verilmiştir.

Tablo 2: Güvenirlik Testi Sonuçları

\begin{tabular}{l|c|c}
\hline \multicolumn{1}{c|}{ Boyut } & Önerme Sayısı & Cronbach alfa \\
\hline Tükenme & 5 &, 826 \\
\hline Duyarsızlaşma & 4 &, 820 \\
\hline Yetkinlik & 4 &, 591 \\
\hline Yaşam tatmini & 5 &, 809 \\
\hline
\end{tabular}

Yetkinlik boyutunda nispeten düşük bir değer elde edilmiş olsa da bütün boyutlar için güvenirliğin sağlanmış olduğu görülmektedir (Akgül ve Çevik, 2005:435-436). Bu aşamada analize hangi tür testlerle devam edileceğinin belirlenmesi için verilerin normal dağılım gösterip göstermediğinin belirlenmesi gerekmektedir. Bu kapsamda Shapiro-Wilk ve Kolmogorov Smirnov testleri yapılmıştır. Örneklem büyüklüğü ellinin üzerinde olduğu için Kolmogorov Smirnov testi yorumlanmıştır. Bu testin tüm önermeler için istatistikî olarak anlamlı çıktığı gözlenmiştir. $\mathrm{Bu}$ dikkate alındığında elde edilen verilerin normal dağılım göstermediği belirlenmiş ve nonparametrik testlerle analize devam edilmiştir. Dolayısıyla demografik özelliklerin ankette sorulan önermelerde anlamlı bir farklılık oluşturup oluşturmadığının anlaşılması için Mann Whitney $U$ ve Kruskall Wallis testleri, çoklu ilişkilerin değerlendirilmesinde Spearman korelasyonu kullanılmıştır. Ancak verinin kolay yönetilebilmesi adına boyutlarla ilgili yöneltilen önermelerin aritmetik ortalamalarının alınması gerekmektedir. Bu boyutların ayrışmasının keşfedilebilmesi için Keşif Amaçlı Faktör Analizine (KAFA) ihtiyaç duyulmaktadır.

Tablo 3: Tükenmişliğin Yaşam Tatminine Etkisine Yönelik Anketin KMO ve Bartlett Testi Sonuçları

\begin{tabular}{l|c|c}
\hline \multicolumn{3}{l}{ KMO and Bartlett's Test } \\
\hline KMO & $\mathbf{x}^{\mathbf{2}}$ &, 854 \\
\cline { 2 - 3 } & $\mathbf{S d}$ & 3307,270 \\
\cline { 2 - 3 } & $\mathbf{p}$ & 153 \\
\hline
\end{tabular}

Faktör analizi yapmak için yeterli örneklem büyüklüğünün elde edilip edilmediğinin belirlenmesi için ilk olarak Kaiser-Meyer-Olkin (KMO) ve Bartlett testi yapılmıştır. Faktör analizinin uygulanabilmesi için KMO değerin en az 0,5 olması gerekmektedir. Bu değer $>, 9$ ise mükemmel, $>, 8$ ise çok iyi, $>, 7$ ise iyi, $>, 6$ ise vasat, $>, 5$ ise sınırda kabul edilebilir, $<, 5$ ise kabul edilemez olarak nitelendirilir (George ve Mallery, 2016:264). Tablo 3'te görüleceği gibi yapılan analiz sonucu KMO değerinin 0,854 olarak çok iyi olduğu gözlenmiş olup, bu değer 
çalışmanın yeterli örneklem büyüklüğüne sahip olduğunu göstermektedir. Müştereklik tablosu incelendiğinde 0,5 'in üzerinde değeri olan önermelerin faktör analizinde bir başka önermeye benzeşme oranlarının yüksek olduğu gözlenmektedir. Ancak 0,5 'in altında kalan değerlerin faktör analizi sonunda bir boyutun altında listelenmesi güç görünmektedir.

Yapılan faktör analizi sonucunda ölçeğin orijinal boyutları olan dört boyutlu bir yapı ortaya çıkmıştır ve açıklanan varyans oranı ise dört faktör için \%58,8'dir. Açıklanan toplam varyans incelendiğinde kapsam geçerliği bakımından bir problemin olmadığı gözlenmektedir (Yaşlığlu, 2017:77). Böylece ölçeğin hem güvenilir hem de geçerliği olduğuna dair uygun veriler elde edilmiştir. Tablo 4 'te faktör analizi sonucu elde edilen alt boyutların öz değerleri ve açıkladıkları varyans değerleri verilmiştir.

Tablo 4: Maddelerin Özdeğerleri ve Açıklanan Varyans Oranları

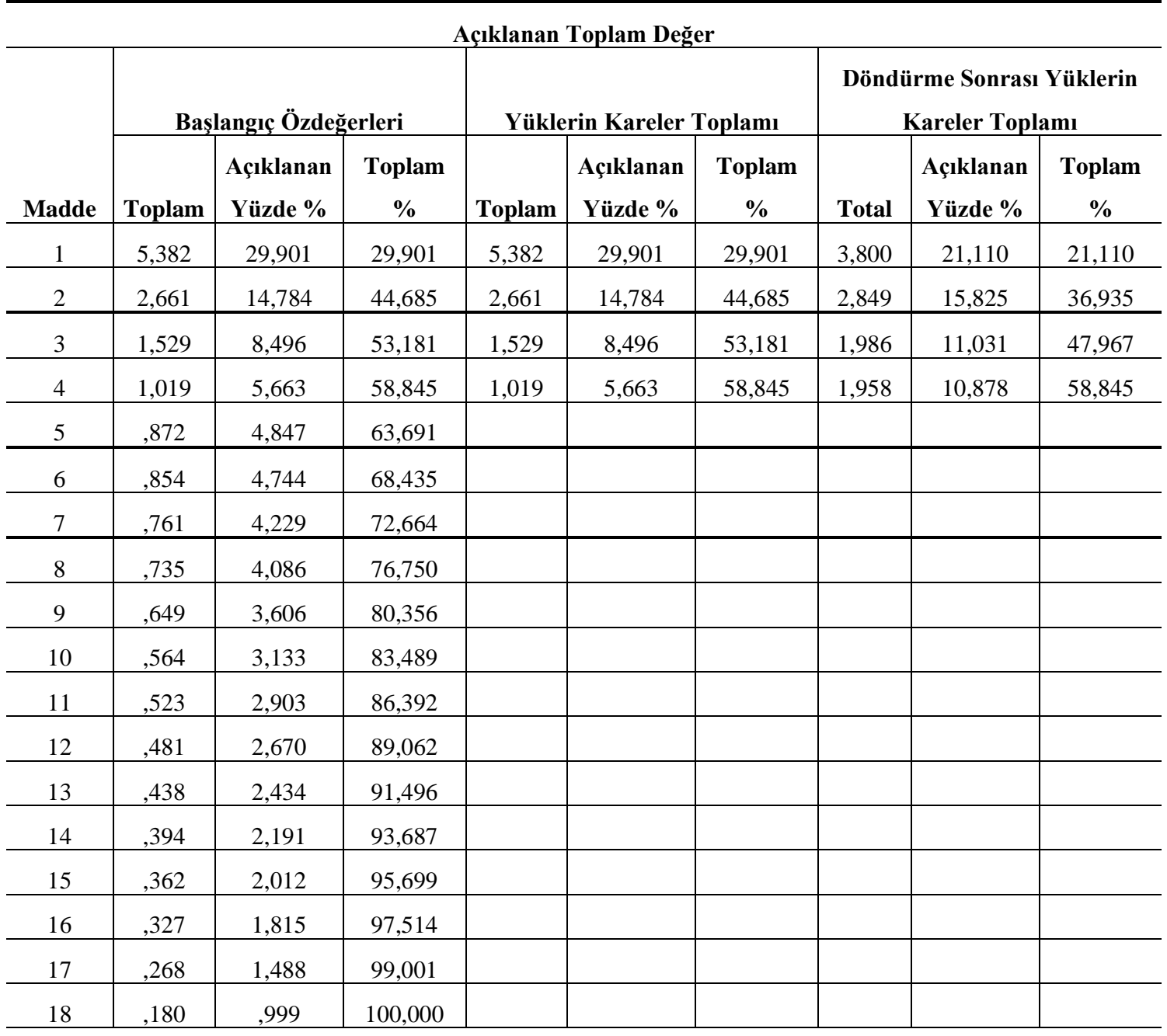

Döndürme Yöntemi: Temel Bileșenler Analizi

Döndürülmüş bileşenler matrisi Tablo 5 'te verilmiştir. $\mathrm{Bu}$ tablo incelendiğinde Tükenmişlik Ölçeği'nin orijinalinde duyarsızlaşma boyutunda olan birinci ve ikinci önermelerinin duyarsızlaşma boyutu yerine tükenme boyutuna yüklendiği dikkati çekmiştir. Bunun dışında bütün faktörler ölçeklerin orijinal boyutlarına yüklenmişlerdir. Dolayısıyla faktör analizi sonunda elde edilen döndürülmüş bileşenler matrisi ilişkilerin dört boyut altında 
incelenebileceğini göstermektedir. Ancak duyarsızlaşma ile ilgili ilk ve ikinci önermenin analiz kapsamından çıkarılması gerekmektedir. $\mathrm{Bu}$ işlem neticesinde verinin modeli temsil kabiliyetinin olup olmayacağının testi için Doğrulayıcı Faktör Analizi yapılmıştır.

Tablo 5: Döndürülmüș Bileșenler Matrisi

\begin{tabular}{|c|c|c|c|c|}
\hline & \multicolumn{4}{|c|}{ Bileşenler } \\
\hline & 1 & 2 & 3 & 4 \\
\hline Tükenme_1 &, 731 & & & \\
\hline Tükenme_2 &, 740 & & & \\
\hline Tükenme_3 &, 770 & & & \\
\hline Tükenme_4 & ,620 & & & \\
\hline Tükenme_5 &, 813 & & & \\
\hline Duyarsızlaşma_1 & ,650 & & & \\
\hline Duyarsızlaşma_2 & ,678 & & & \\
\hline Duyarsızlaşma_3 & & & & ,787 \\
\hline Duyarsızlaşma_4 & & & &, 857 \\
\hline Yetkinlik_1 & & &, 577 & \\
\hline Yetkinlik_2 & & &, 596 & \\
\hline Yetkinlik_3 & & &, 707 & \\
\hline Yetkinlik_4 & & & ,662 & \\
\hline Yaşam_tatmini_1 & &, 700 & & \\
\hline Yaşam_tatmini_2 & &, 815 & & \\
\hline Yaşam_tatmini_3 & &, 754 & & \\
\hline Yaşam_tatmini_4 & &, 723 & & \\
\hline Yaşam tatmini 5 & & ,659 & & \\
\hline
\end{tabular}

Takip eden Şekil 1'de verilen doğrulayıcı faktör analizi sonucu elde edilen değerler modelin istatistiki olarak doğrulandığını göstermektedir $(\mathrm{CMIN} / \mathrm{df}=1,646$; NFI=,939; RFI: ,925; IFI= ,975; TLI=,969; CFI=,975; RMSEA=,037) (Yaşlığlu, 2017:77; Birincioğlu ve Tekin, 2018:179; Doğan, 2015:29). Böylece Keşif amaçlı Faktör Analizi (KAFA) ve Doğrulayıc1 Faktör Analizi (DFA)'nın gösterdiği şekliyle aritmetik ortalamaların faktör analizindeki boyutlara göre şekillendirilmesi sağlanmıştır. Bu analiz doğrultusunda yaşam tatmini ölçeğinin orijinal boyutlara uygun şekilde doğrulandığ 1 ve tükenmişlik ölçeğinin duyarsızlaşma boyutunun ilk iki maddesi dışında doğrulandığı görülmektedir. Yapılan analizde duyarsızlaşma boyutunun bu iki maddesinin tükenme boyutuna yüklendiği belirlenmiştir. 


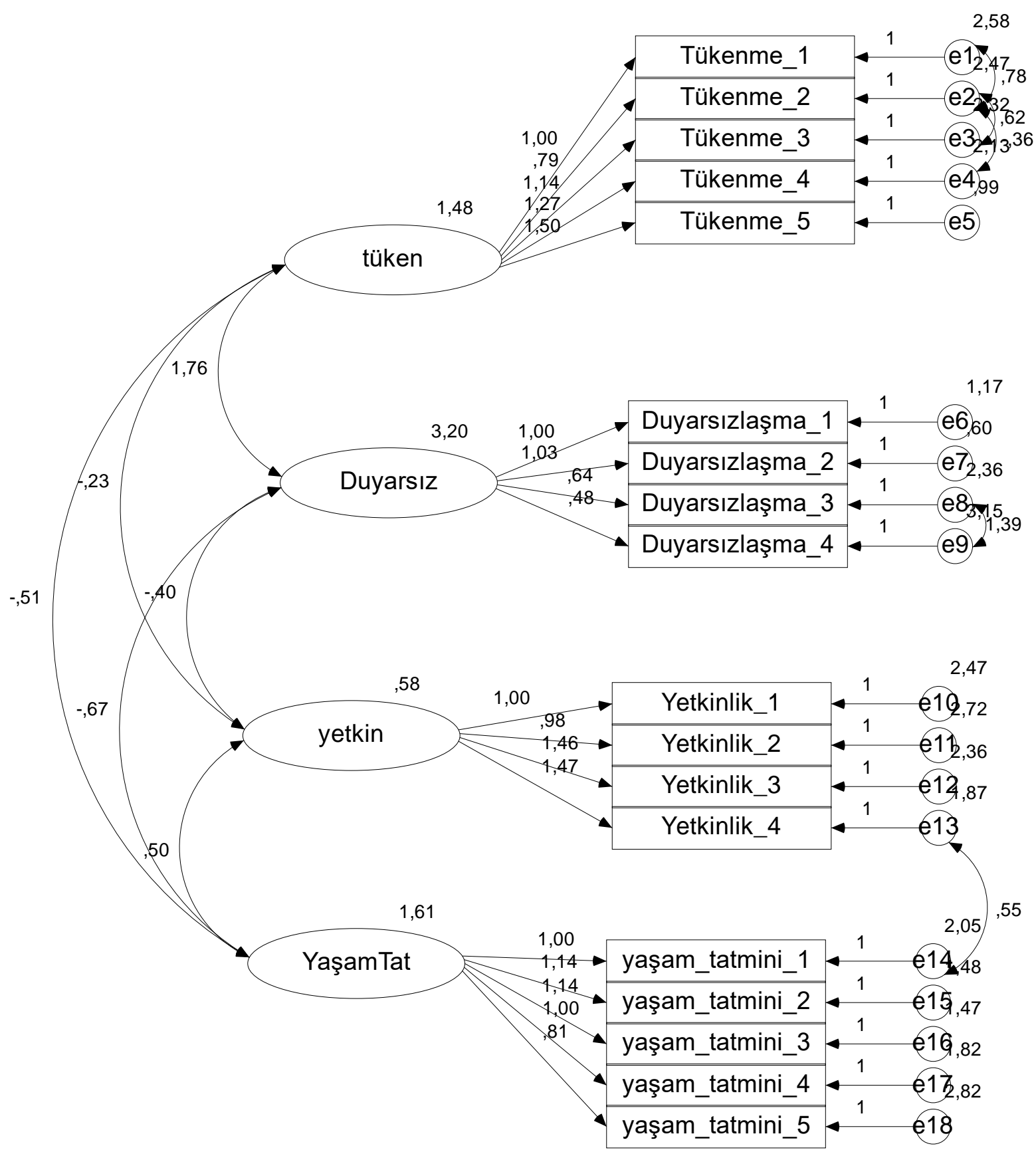

Şekil 1: Doğrulayıcı Faktör Analizi Sonuçları

\section{BULGULAR}

Araştırmada kullanılan her iki ölçekteki ifadeler 7'li likert ölçeğine göre oluşturulmuştur. Anket yedi seçenek ve altı fark aralığına sahip olduğu için $6 / 7=0,86$ 'lik bir fark aralığı hesaplanmıştır. Ölçeklerin ortalama değer aralıklarını belirleyen puanlar ise aşağıda sıralandığı gibi kabul edilmiştir. Katılımcıların ortalama puanındaki artış ilgili değişkenin algılanan düzeyinin arttığını göstermektedir. 
$1,00<\overline{\mathrm{X}}<1,86$ aralığında çok çok düşük,

$1,87<\overline{\mathrm{X}}<2,72$ aralığında çok düşük,

$2,73<\overline{\mathrm{X}}<3,58$ aralığında düşük,

$3,59<\overline{\mathrm{X}}<4,44$ aralığinda orta ve

$4,45<\overline{\mathrm{X}}<5,30$ yüksek

$5,31<\overline{\mathrm{X}}<6,16$ çok yüksek

$6,17<\overline{\mathrm{X}}<7,00$ aralığında çok çok yüksektir.

Tablo 6: Betimleyici İstatistikler

\begin{tabular}{l|c|c|c|c|c}
\hline & $\mathbf{N}$ & Minimum & Maximum & Ortalama & Standart Sapma \\
\hline Tükenme & 475 & 1,20 & 7,00 & 4,5263 & 1,55985 \\
\hline Duyarsızlaşma & 475 & 1,00 & 7,00 & 3,9568 & 1,75135 \\
\hline Yetkinlik & 475 & 1,00 & 7,00 & 4,6079 & 1,21287 \\
\hline Yaşam Tatmini & 475 & 1,00 & 7,00 & 3,5566 & 1,43350 \\
\hline
\end{tabular}

Aritmetik ortalamalar bağlamında öğrencilerin algılamış oldukları tükenmenin 4,5263 ( \pm $1,55 \mathrm{ss})$ yüksek düzeyde olduğu tespit edilmişken, duyarsızlaşma ise 3,9568 ( $\pm 1,75 \mathrm{ss})$ orta düzeydedir. Yetkinlik boyutundaki değer 4,6079 ( $\pm 1,21 \mathrm{ss})$ ise öğrencilerin kendilerini yüksek düzeyde yetkin bulduklarını gösterirken, yaşam tatmini düzeyinin 3,5566 $( \pm 1,43 \mathrm{ss})$ düşük olduğu bulgusuna ulaşılmıştır. Demografik faktörler açısından anlamlı farklılıkların olup olmadığ1 gerçekleştirilen nonparametrik testlerle değerlendirilmiştir. Makalenin içeriğini karmaşık hale dönüştürmemek için bu analiz sonucu sadece anlamlı çıan veya önemli olduğu düşünülen ilişkilere yer verilmiştir.

Tablo 7: Cinsiyete Göre Mann Whitney U Testi Sonuçları

\begin{tabular}{l|c|c|c|c}
\hline & Tükenme & Duyarsızlaşma & Yetkinlik & Yaşam Tatmini \\
\hline Mann-Whitney U & 22322,500 & 25583,000 & 27251,000 & 25933,500 \\
\hline Wilcoxon W & 42825,500 & 46086,000 & 64652,000 & 63334,500 \\
\hline Z & $-3,554$ & $-1,351$ &,- 218 & $-1,110$ \\
\hline Anlamlılık &, 000 &, 177 &, 827 &, 267 \\
\hline
\end{tabular}

a. Bağımsız Değişken: Cinsiyet

Cinsiyet açısında değerlendirildiğinde tükenme boyutunda anlamlı bir farkın olduğu belirlenmiştir. Ortalamalar karşılaştırıldığında kız öğrencilerin 4,44 (1,44 ss) erkeklere 4,02 $(1,40467$ ss) oranla daha yüksek tükenmişlik algısına sahip oldukları gözlenmiştir (Tablo 7). Diğer ifade ile kız öğrenciler erkek öğrencilere göre daha fazla tükenmişlik yaşamaktadırlar. 
Tablo 8: Mesleği Önermeye Göre Mann Whitney U Testi Sonuçları

\begin{tabular}{l|c|c|c|c}
\hline & Tükenme & Duyarsızlaşma & Yetkinlik & $\begin{array}{c}\text { Yaşam } \\
\text { Tatmini }\end{array}$ \\
\hline Mann-Whitney U & 21154,000 & 21856,000 & 22079,000 & 20477,500 \\
\hline Wilcoxon W & 36554,000 & 37256,000 & 67229,000 & 65627,500 \\
\hline Z & $-3,535$ & $-3,058$ & $-2,896$ & $-4,004$ \\
\hline Anlamlılık &, 000 &, 002 &, 004 &, 000 \\
\hline
\end{tabular}

a. Bağımsız Değişken: Mesleği Önerme

Mesleği önermeye göre bütün boyutlar için anlamlı farklılıkların olduğu belirlenmiştir (Tablo 8). Mesleği önerenlerin tükenme ve duyarsızlaşma boyutlarında düşük algıya sahip oldukları ancak yetkinlik ve yaşam tatmini boyutları açısından algılarının yüksek olduğu belirlenmiştir.

Tablo 9: Mesleği Seçmeye Göre Mann Whitney U Testi Sonuçları

\begin{tabular}{l|c|c|c|c}
\hline & Tükenme & Duyarsızlaşma & Yetkinlik & $\begin{array}{c}\text { Yaşam } \\
\text { Tatmini }\end{array}$ \\
\hline Mann-Whitney U & 17338,000 & 21619,000 & 23219,000 & 17814,500 \\
\hline Wilcoxon W & 58666,000 & 62947,000 & 40985,000 & 35580,500 \\
\hline Z & $-6,596$ & $-3,679$ & $-2,575$ & $-6,270$ \\
\hline Anlamlılık &, 000 &, 000 &, 010 &, 000 \\
\hline
\end{tabular}

a. Bağımsız Değişken: Mesleği Seçme

Mesleği seçme değişkeni bağlamında bütün boyutlarda anlamlı farklılıkların olduğu belirlenmiştir (Tablo 9). Sonuç olarak mesleği isteyerek seçenlerin tükenme ve duyarsızlaşma algıları düşükken, yetkinlik ve yaşam tatmini algılarının yüksek olduğu belirlenmiştir.

Yapılan Kruskal Wallis testi sonucunda öğrencilerin okudukları bölümler açısından aralarında anlamlı bir fark olmadığ 1 tespit edilmiştir (Tablo 10). Başka bir deyişle örneklemdekiler bölümlerine bakılmaksızın tükenme, duyarsızlaşma, yetkinlik ve yaşam tatmini konularında aynı düşünceleri paylaşmaktadırlar.

Tablo 10: Öğrencilerin Okudukları Bölümlere Göre Kruskal Wallis Testi Sonuçları

\begin{tabular}{l|c|c|c|c}
\hline & Tükenme & Duyarsızlaşma & Yetkinlik & Yaşam Tatmini \\
\hline Ki-Kare & & & & \\
\hline Serbestlik Derecesi & 4,524 & 4,422 & 3,655 & 4,289 \\
\hline P değeri (Anlamııık) &, 074 & 4 & 4 & 4 \\
\hline
\end{tabular}

a. Bağımsız Değişken: Okunan Bölüm

Tablo 11'de görüleceği gibi katılımcıların annelerinin eğitim durumuna göre istatistiksel olarak anlamlı farkın sadece yaşam tatmini boyutunda olduğu gözlenmiştir $(\mathrm{p}<0.05)$. Buna göre annesi okur yazar olmayan grubun yaşam tatmini ortalaması 3,35 (1,44 ss) iken annesi üniversite mezunu grubun yaşam tatmini algısı 4,18 (1,32ss)'dir ve yüksekokul mezunu anne grubu 
dışındaki diğer grupların tamamında annelerin eğitim düzeyi yükseldikçe katılımcıların yaşam tatmini algısı yükselmektedir.

Tablo 11: Annenin Eğitim Düzeyine Göre Kruskal Wallis Testi Sonuçları

\begin{tabular}{l|c|c|c|c}
\hline & Tükenme & Duyarsılaşma & Yetkinlik & Yaşam Tatmini \\
\hline Ki-Kare & 1,400 & 2,818 & 1,929 & 11,288 \\
\hline Serbestlik Derecesi & 4 & 4 & 4 & 4 \\
\hline P değeri (Anlamlılık) &, 844 &, 589 &, 749 &, 024 \\
\hline
\end{tabular}

a. Bağımsız Değişken: Annenin eğitim düzeyi

Babalarının eğitim durumu açısından yine sadece yaşam tatmininde anlamlı $(\mathrm{p}<0.000)$ bir farkın olduğu bulgusuna ulaşılmıştır (Tablo 12). Okur yazar olmayan babaların çocuklarının yaşam tatmini algısı ortalaması 3,66 (1,71 ss) iken üniversite mezunlarının 3,93 (1,46 ss), yüksekokul mezunu olanların 4,40 (1,21 ss) olduğu belirlenmiştir. Buna göre babalarının eğitim düzeyinin yükselmesi ile doğru orantılı bir şekilde katılımcıların yaşam tatmini algılarının yükseldiği gözlemlenmektedir.

Tablo 12: Babaların Eğitim Durumuna Göre Kruskal Wallis Testi Sonuçları

\begin{tabular}{l|c|c|c|c}
\hline & Tükenme & Duyarsızlaşma & Yetkinlik & Yaşam Tatmini \\
\hline Ki-Kare & 8,281 & 2,562 & 4,674 & 21,601 \\
\hline Serbestlik Derecesi & 4 & 4 & 4 & 4 \\
\hline P değeri (Anlamlıık) &, 082 &, 634 &, 322 &, 000 \\
\hline
\end{tabular}

a. Bă̆ımsız Değişken: Baba Eğitim Düzeyi

Ailenin gelir durumu için yapılan Kruskal Wallis testi değerlendirildiğinde sadece yaşam tatmini açısından istatistiksel olarak anlamlı bir farklılı̆̆ın olduğu gözlenmiştir (Tablo 13). Ortalamalar karşılaştırıldığında aylık gelir düzeyi algısı arttıkça yaşam tatminin de arttığ belirlenmiştir.

Tablo 13: Ailenin Gelir Durumuna Göre Kruskal Wallis Testi Sonuçları

\begin{tabular}{l|c|c|c|c}
\hline & Tükenme & Duyarsızlaşma & Yetkinlik & Yaşam Tatmini \\
\hline Ki-Kare & 4,055 & 1,265 & 2,410 & 7,342 \\
\hline Serbestlik Derecesi & 4 & 4 & 4 & 4 \\
\hline P değeri (Anlamlılık) &, 132 &, 531 &, 300 &, 025 \\
\hline
\end{tabular}

Bağımsız Değişken: Ailenin Gelir Durumu

Sınıf düzeyi bağlamında katılımcıların tükenmişlik ve duyarsızlaşma algılarında anlamlı farklılıkların olduğu gözlenmektedir (Tablo 14). Tükenmişlik boyutunda son sınıfların, duyarsızlaşma konusunda da üçüncü sınıfların daha yüksek algılarının olduğu belirlenmiştir. 
Tablo 14: Sınıf Düzeyine Göre Kruskal Wallis Testi Sonuçları

\begin{tabular}{l|c|c|c|c}
\hline & Tükenme & Duyarsızlaşma & Yetkinlik & Yaşam Tatmini \\
\hline Ki-Kare & 8,653 & 15,625 &, 821 & 1,370 \\
\hline Serbestlik Derecesi & 3 & 3 & 3 & 3 \\
\hline P dě̆eri (Anlamlıık) &, 034 &, 001 &, 844 &, 713 \\
\hline
\end{tabular}

a. Bağımsız Değişken: Okunan sınıf

Kardeş sayısı açısından yapılan analiz sonucu istatistiksel olarak anlamlı olan tek farklılık yaşam boyutu açısından bulgulanmıştır (Tablo 15). Bir kardeşi olanların yaşam tatmin algısı ortalaması 3,8095 (1,51026 ss) iken dör ve üzeri kardeşi olanların yaşam tatmini algisı 3,4035 $(1,36698 \mathrm{ss})$. Buna göre kardeş sayısı daha az olanların yaşam tatmin algıları daha yüksektir.

Tablo 15: Kardeș Sayısına Göre Kruskal Wallis Testi Sonuçları

\begin{tabular}{l|c|c|c|c}
\hline & Tükenme & Duyarsızlaşma & Yetkinlik & Yaşam Tatmini \\
\hline Ki-Kare & 1,739 & 7,815 & 1,908 & 9,234 \\
\hline Serbestlik Derecesi & 3 & 3 & 3 & 3 \\
\hline P değeri Anlamlılık) &, 628 &, 050 &, 592 &, 026 \\
\hline \multicolumn{4}{l}{ a. Bağımsız Değişken: Kardeș Sayısı }
\end{tabular}

Katılımcı öğrencilerin barınma yerlerine göre istatistiksel olarak anlamlı farklılı̆̆ın olup olmadığını belirlemek için yapılan Kruskal Wallis testi sonuçlarına göre sadece yaşam tatmini boyutunda bir farklılık belirmiştir (Tablo 16). Yaşam tatmini algısı en yüksek grup evde tek başına yaşayanlar iken, bunları ailesi ile birlikte kalanlar takip etmektedir.

Tablo 16: Kalınan Yere Göre Kruskal Wallis Testi Sonuçları

\begin{tabular}{l|c|c|c|c}
\hline & Tükenme & Duyarsızlaşma & Yetkinlik & Yaşam Tatmini \\
\hline Ki-Kare & 3,954 & 5,484 & 1,837 & 19,781 \\
\hline Serbestlik Derecesi & 3 & 3 & 3 & 3 \\
\hline P değeri (Anlamlıık) &, 266 &, 140 &, 607 &, 000 \\
\hline
\end{tabular}

a. Bağımsız Değişken: Kalınan Yer

Katılımcı öğrencilerin üniversiteye kayıt olmadan yaşadıkları yerlere göre anlamlı bir farklılık olup olmadığını belirlemek için yapılan analiz sonucunda anlamlı bir farkın olmadığı belirlenmiş̧ir. Buna göre il, ilçe, köy gibi üniversiteye kayıt olmadan önce yaşanılan yerler öğrencilerin tükenme, duyarsızlaşma, yetkinlik ve yaşam tatmini algılarını etkilememektedir denilebilir.

Katılımcı öğrencilerin demografik özellikleri dikkate alınarak yapılan analiz sonuçlarını özetlemek gerekirse anlamlı farklılıkların özellikle yaşam tatmini boyutunda gerçekleştiği, diğer boyutlarda anlamlı farklılıkların daha az olduğu gözlemlenmiştir. Cinsiyet açısından kız öğrencilerin tükenme algısı erkek öğrencilere göre daha yüksektir. Mesleği isteyerek seçenler ve önerebileceklerini söyleyen katılımcı öğrencilerin tükenme ve duyarsızlaşma algıları düşük iken, yetkinlik ve yaşam tatmini algıları ise diğerlerine göre yüksektir. Bu değerlendirme bölümden 
mezun olunduğunda alanla ilgili mesleğin seçileceği varsayımı dikkate alınarak yapılmıştır. Anne ve babanın eğitim seviyesinin yükselmesi ile katılımcı öğrencilerin yaşam tatmini algıları arasındaki ilişki de olumludur. Yine ailenin gelir düzeyi yükseldikçe yaşam tatmini algısı da artmaktadır. Son sınıflar diğer bütün sinıflara göre tükenme algıları en yüksek sınıf iken, üçüncü sınıflarda okuyan öğrencilerin duyarsızlaşma algısının diğer sınıflara nazaran yüksek olduğu gözlenmiştir. Kardeş sayısı az olanlar ile evde tek başına ikamet eden katılımcı öğrencilerin yaşam tatmini algılarının diğer katılımcılara göre yüksek olduğu belirlenmiştir. Boyutlarla ilgili demografik özelliklerdeki farklılıkların gösteriminden sonra bu boyutlar arasındaki ilişkilerin incelenmesi sayesinde hipotezlerin test edilebileceği düşünülmüştür.

Tablo 17: Değişkenler Arası İlişkiler Tablosu

\begin{tabular}{l|c|c|c}
\hline & Tükenme & Duyarsızlaşma & Yetkinlik \\
\hline Duyarsılaşma &, $453^{* *}$ & & \\
\hline Yetkinlik &,$- 123^{* *}$ &,$- 174^{* *}$ & \\
\hline Yaşam tatmini &,$- 252^{* *}$ &,$- 170^{* *}$ &, $343^{* *}$ \\
\hline
\end{tabular}

Tablo 17'nin incelenmesiyle görüleceği gibi tükenme boyutu ile duyarsızlaşma arasında olumlu ve anlamlı bir ilişki bulunmuştur $(\mathrm{r}=0,453 ; \mathrm{p}<0,01)$. Buna göre tükenme algısı arttıkça yaşanılan duyarsızlaşma da artmaktadır. Tükenme boyutu ile yetkinlik arasında negatif bir ilişki vardır $(\mathrm{r}=-0,123 ; \mathrm{p}<0,01)$. Algılanan tükenme katılımcıların algıladıkları yetkinliklerini azaltmaktadır. Katılımcı öğrencilerin tükenme algısı ile yaşam tatmini arasında da negatif bir ilişki bulunmaktadır $(\mathrm{r}=-0,252 ; \mathrm{p}<0,01)$. Bunun anlamı algılanan tükenme yaşam tatminine olumsuz yansımaktadır. Duyarsızlaşmanın yetkinlik $(r=-0,174 ; p<0,01)$ ve yaşam tatmini $(r=-$ $0,170 ; p<0,01)$ ile negatif yönde ilişkili olduğu belirlenmiştir. Dolayısıyla duyarsızlaşma hem yetkinlik hem de yaşam tatmini ile olumsuz ilişki göstermektedir. Son olarak yetkinlik ile yaşam tatmini arasında pozitif ve istatistiki olarak anlamlı bir ilişki tespit edilmiştir $(r=0,343 ; p<0,01)$. Yetkinliğin artışı yaşam tatmine olumlu yansımaktadır.

Bu bulgular doğrultusunda tükenme ve duyarsızlaşma boyutları ile yaşam tatmini arasında negatif yönlü, yetkinlik boyutu ile yaşam tatmini arasında pozitif yönlü bir ilişkinin varlığı belirlenmiştir ve araştırma hipotezleri kabul edilmiştir.

\section{TARTIŞMA VE SONUÇ}

$\mathrm{Bu}$ araştırmanın temel amacı üniversite öğrencilerinin algıladıkları tükenmişlik boyutları ile yaşam tatmini arasındaki ilişkileri ortaya koymaktır. Bunun yanında bazı demografik değişkenlerle yine katılımcı öğrencilerin algıladıkları tükenme, duyarsızlaşma, yetkinlik ve yaşam tatmini arasındaki ilişkilerin belirlenmesi de bu araştırmanın ikincil amacıdır. Araştırma Kahramanmaraş Sütçü İmam Üniversitesi İ̈BF öğrencilerinin oluşturduğu ve oldukça yüksek sayılabilecek $(\mathrm{n}=475)$ bir örneklem ile gerçekleştirilmiştir. Aritmetik ortalamalar bağlamında değerlendirildiğinde katılımcı öğrencilerin algıladıkları tükenmenin ve yetkinliğin yüksek düzeyde, duyarsızlaşmanın orta düzeyde olduğu gözlemlenirken, yaşam tatmini düzeyinin ise düşük olduğu belirlenmiştir.

Öğrenciler arasında tükenme boyutundaki yüksek algının literatürle uyumlu olduğu görülmektedir. Aslında gençler arasında tükenmişliğin 30-40'lı yaşlara göre yüksek olduğu (Maslach, Schaufeli ve Leiter, 2001:409) ve yine üniversite öğrencileri arasında tükenmişliğin 
yaygın bir fenomen olduğu birçok araştırma tarafindan ortaya konulmuştur (Lingard, 2007:99; Gündüz, Çapri ve Gökçakan, 2012:44; Tansel, 2015:246; Bayrakdar, 2016:940). Buna karș1l1k yaşam tatmini konusundaki olumsuz algılamanın literatürle kısmen uyumlu olduğu görülmektedir. Öztürk ve Ünal (2019:67) üniversite öğrencilerinin katkıda bulunduğu bir çalışmada yaşam tatmin düzeyini yüksek, Gökalp ve Topal (2019:200) ise orta düzeyde bulmuşlardır. Yine Çağatay İn ve Şanlı Kula (2019:432) üniversite öğrencileri kapsamında yaptıkları çalışmada öğrencilerin \%46'sının yaşam tatminin düşük, \%54'ünün ise yüksek olduğu bulgusuna ulaşmışlardır. Pınar vd. (2015:287) çalışmasında ise diş hekimliği fakültesi öğrencilerinin yaşam tatmini puanları düşük, ebelik bölümü öğrencilerinin ise yaşam tatmini puan ortalamalarının yüksek olduğu belirlenmiştir. Bu bulgular üniversite öğrencilerinin yaşam tatmin düzeyleri konusunda yorum yapmayı zorlaştırmaktadır. Elbette ki yaşam tatmini etkileyebilecek çok sayıda değişken söz konusudur. Öğrenciler üniversite yıllarında sosyal, kişisel, akademik ve kariyer planlama konularında üstesinden gelmeleri gereken problemlerle karşı karşıya kalabilmektedirler. Bu faktörler yaşam tatminlerini azaltıcı bir işlev üstlenebilir (Özbay, Palancı, Kandemir ve Çakır, 2012:325). Ayrıca yaşam tatmini düzeylerinin örneklemler bağlamında düşünülmesi de dikkate alınmalıdır. Mesela Tuzgöl Dost (2010:86) Türk ve Güney Afrikalı üniversite öğrencilerinin yaşam tatminlerini karşılaştırdığı çalışmasında Güney Afrikalı öğrencilerin yaşam tatmin düzeylerinin Türk öğrencilerden yüksek olduğunu belirlemiş ve bu farklılığın ulusal kültürler, gelir ve yaşam koşulları bağlamında yorumlanabileceğini belirtmiştir. Bu çalışmamızda da katılımcıların büyük bir çoğunluğu gelir düzeylerini orta $(n=374: \% 78,7)$ ve düşük $(\mathrm{n}=53$ : \%11,2) olarak algılamaktadırlar. Bu noktadan hareketle çalışmada yaşam tatmininin düşük algılanması gelirle ilgili olabileceği gibi hayatın daha başlangıcı denilebilecek bir noktada başta kariyer olmak üzere yaşanılabilecek gelecek kaygısı da bu sonuçta rol oynamış olabilir.

Demografik değişkenlerden cinsiyet bağlamında kız öğrencilerin algıladıkları duygusal tükenme erkek öğrencilere göre anlamlı düzeyde yüksektir. Cinsiyet değişkeni bağlamında literatür çok farklı bulgular içermektedir. Bazı çalışmalarda kişisel başarı ve duyarsızlaşma boyutunda erkek üniversite öğrencilerinin algıları yüksek iken duygusal tükenme de k1z öğrencilerin algıları yüksek çıkmıştır (Ören ve Türkoğlu, 2006; Gündüz, Çapri ve Gökçakan, 2012:41; Çağatay İn ve Şanlı Kula, 2019:412). Yine Tansel (2015:246) duygusal tükenme ve duyarsızlaşma boyutlarında erkek öğrencilerin algılarının kız öğrencilere göre anlamlı derecede yüksek olduğunu belirlemiştir. Buna karşın bazı çalışmalar cinsiyet açısından yaşanan tükenmişliğin anlamlı olmadığını ortaya koymaktadır (Demirel, Yılmaz ve Üngüren, 2015:179; Tümkaya ve Çavuşoğlu, 2010:468). Cinsiyet bağlamında tükenme konusundaki bu farklılıklar sadece Türkiye'de yapılan çalışmalarla ilgili değildir. Aslında cinsiyetin algılanan tükenmenin güçlü bir yordayıcısı olmadığı söylenebilir (Maslach, Schaufeli ve Leiter, 2001:410). Çalışmanın bulgusu ve literatür açısından değerlendirildiğinde cinsiyet bağlamında kesin bir yargı ifade etmenin ihtiyatla yaklaşılması gereken bir konu olduğu görülmektedir. Bununla birlikte bu çalışmada ve az önce değinilen bazı çalışmalarda kızların duygusal tükenme algısının yüksek çıkmasına karşın literatürdeki diğer çalışmalar da dikkate alındığında her iki grubun da tükenme yaşayabilecekleri düşünülebilir.

$\mathrm{Bu}$ çalışmada bölümü isteyerek seçen ve önerebileceğini ifade eden öğrencilerin algıladıkları tükenme ve duyarsızlaşma düzeyi düşük iken yetkinlik ve yaşam tatminlerinin yüksek olduğu tespit edilmiştir. Bu bulgunun literatürle uyumlu olduğu söylenebilir. Nitekim üniversite öğrencileri arasında yapılan bir çalışmada kendi isteğiyle okuduğu bölümü seçen öğrencilerin tükenme düzeyleri yüksek olmasına karşın ailesinin isteği, prestij, ekonomik gerekçelerle okudukları bölümleri tercih eden öğrencilerin az önceki grupla karşılaştırıldığında daha fazla tükenmişlik yaşadıklarını ortaya koyan bir çalışma bulunmaktadır (Tansel, 2015:254). Aslında bu ilişki beklenebilecek bir bulgudur denilebilir. Çünkü bölümü isteyerek seçen ve önerebileceğini söyleyen katılımcıların arzuladıkları bir alanda eğitim gördükleri, dolayısıyla 
bunun algılayabilecekleri tükenme ve duyarsızlaşmayı azaltırken yetkinlik ve yaşam tatminlerini artıracak bir işlev üstlenebileceği beklenebilir. Bu konuda öğrencilerin isteyerek tercih ettikleri bölümlerinde beklentilerinin karşılandığı yorumu da düşünülebilir.

$\mathrm{Bu}$ çalışmanın diğer bir bulgusu anne ve babanın eğitim durumunun yükselmesiyle katılımcıların yaşam tatmini algısının da yükselmesidir. Bu bulgu ile ilgili olarak annenin eğitim seviyesinin artmasıyla çocukların algıladıkları tükenmenin azaldığını ortaya koyan bir çalışma (Wang, Wang, Shi, Li, Liu, Liu vd. 2019:5) dikkate alınarak yorum yapılabilir. Buna göre annenin eğitim seviyesindeki artış çocuklara karşı yaklaşım konusunda annelerin daha bilinçlenmesini sağlayıp, çocuklarının karşı karşıya kalabilecekleri tükenmeyi azaltarak yaşam tatminin artırıyor olabilir. Ayrıca anne ve babaların çocuklarına karşı tutumlarının yaşam tatmini ile ilişkisini ortaya koyan araştırmalar da bulunmaktadır (Milevsky, Schlechter, Netter ve Keehn, 2007:39; Tuzgöl Dost, 2010:87; Pérez-Fuentes, Jurado, Linares, Ruiz, Márquez ve Saracostti, 2019:4045). Yine bu çalışmanın bulgularından olan babanın eğitim düzeyinin yükselmesiyle yaşam tatmininin artışı sonucu için de anne eğitim seviyesine benzer bir yorum yapılabilir. Buna göre eğitim düzeyi yüksek babaların çocuklarına karşı tutumları yaşam tatminlerini artırıcı bir işlev görüyor olabilir.

Öğrencilerin gelir seviyesi arttıkça yaşam tatmini algıları da artmaktadır ve literatürle uyumlu bir bulgudur. Aslında yaşam tatmini ile en istikrarlı ilişkiye sahip değişkenin gelir olduğu iddia edilebilir (Diener, Diener ve Diener, 1995:852; Møller, 1996:16; Tuzgöl Dost, 2010:85; Chow, 2005:145; Demirel, Y1lmaz ve Üngören, 2015:182; Pınar vd., 2015:290; Çağatay İn ve Şanlı Kula, 2019:424). Gelir hayatta birçok ihtiyacın karşılanmasında önemli bir araç olduğu gibi, kişinin toplumdaki statüsünün belirlenmesindeki etkisinden dolayı yaşam tatmini ile anlamlı ilişkisi olan bir değişkendir denilebilir. Dolayısıyla gelir düzeyinin artmasının kişinin hayat tatmininin artışında önemli bir katkısı olabilecektir.

Sınıf düzeyinde değerlendirildiğinde son sınıfların yaşadıkları tükenmenin diğer sinıflardan anlamlı düzeyde yüksek olduğu belirlenmiştir ve literatürle uyumlu bir bulgudur (Gündüz, Çapri ve Gökçakan, 2012:50; Tansel, 2015:251; Çağatay İn ve Şanlı Kula, 2019:432). Son sınıfların mezun olup, yeni bir yaşama başlama, iş bulabilme kaygısı gibi düşünceleri algılanan tükenmeyi artırabilecek olgulardır. Duyarsızlaşma algısının üçüncü sınıflarda anlamlı düzeyde yüksek olması da literatürle uyumludur denilebilir. Diğer bazı çalışmalarda da sınıf düzeyi yükseldikçe duyarsızlaşmanın artışı dikkat çekmektedir (Tansel, 2015:253; Seçer, 2015:89; Çağatay İn ve Şanlı Kula, 2019:415). Bu sonuç tıpkı tükenmişlik konusunda ilk yıllarda son derece idealist olan insanların daha sonra bu özelliklerini kaybetmeleri durumunda olduğu gibi, öğrencilerin de üniversitenin ilk yıllarında idealist bir düşünceye sahip olup daha sonraları bunu yavaş yavaş kaybettikleri anlamına gelebilir. Kardeş sayısı açısından değerlendirildiğinde daha az kardeşe sahip olanların yaşam tatmini algısının yüksek olduğu belirlenmiştir ve literatürle uyumludur denilebilir (Çağatay İn ve Şanlı Kula, 2019:422). Yine Demir (2020:802) tarafından yapılan ve kardeş durumunun mutluluk üzerine etkisini araştıran bir çalışmada da istatistiksel olarak anlamlı olmasa da mutluluk algısı en yüksek olanların tek kardeşe sahip olanlar olduğu belirlenmiştir. Kardeş sayısını az olması ailenin imkanlarının mevcut kardeşler arasında paylaşımı ve belki de katılımcı öğrenciler açısından daha fazla ilgi ve imkân anlamına geliyor olabilir. Bunlar ise yaşam tatmininin diğer gruplara göre daha yüksek algılanmasına yol açabilir. Evde tek başına kalan öğrencilerin yaşam tatmini ailesi ile birlikte kalan veya yurtta kalan öğrencilere göre daha yüksek bulunmuştur ve literatürle kısmen uyumlu olmadığ 1 belirtilmelidir. Üniversite öğrencilerinin katkıda bulunduğu bir çalışmada kalınan yerin tükenme açısından anlamlı bir farklılık oluşturmadığ 1 tespit edilmesine rağmen (Tümkaya ve Çavuşoğlu, 2010:475), Çağatay İn ve Şanlı Kula (2019:420)'nın yaptığı diğer bir çalışmada ise özel yurtlarda kalan öğrencilerin duyarsızlaşma algısının devlet yurdu, apart ve evde kalan öğrencilerden anlamlı düzeyde daha düşük olduğu bulgusuna ulaşılmıştır. Barınma yeri yaşam kalitesinin bir sembolüdür ve fiziksel sağlık ve psikolojik refah açısından birey için farklı 
faydalar sunmaktadır (Chow, 2005:146). Ayrıca evde tek başına kalma imkanına sahip öğrencilerin gelir düzeyi açısından iyi bir durumda oldukları ve bir ölçüde hareket serbestisine sahip olabilecekleri göz ardı edilmemelidir. Dolayısıyla kalınan yer ile yaşam tatmini arasındaki ilişkinin varlığı bir ölçüde mâkul kabul edilebilir.

Çalışmanın verilerinin analizleri bu çalışma için geliştirilen hipotezleri desteklemektedir ve kabul edilmişlerdir. Buna göre algılanan duygusal tükenmenin $(r=-0,252, p<, 01)$ ve duyarsızlaşmanın $(\mathrm{r}=-0,170, \mathrm{p}<, 01)$ yaşam tatmini ile negatif yönlü, yine algılanan yetkinlik düzeyinin $(r=0,343, p<, 01)$ yaşam tatmini ile pozitif yönlü anlamlı ilişkileri söz konusudur. Buna göre algılanan tükenme ve duyarsızlaşmanın artışı yaşam tatmininde olumsuz, buna karşın algılanan yetkinliğin artışı ile yaşam tatmini arasında olumlu bir ilişki olduğu anlamına gelmektedir. Bu bulgular beklenebilir bulgulardır ve literatürle büyük ölçüde uyumlu olduğu görülmektedir. Çağatay İn ve Şanlı Kula (2019:411)'nın üniversite öğrencileri dahilinde yaptıkları çalışmada da duygusal tükenme, duyarsızlaşma ve yaşam tatmini arasında negatif yönde zayıf, buna karşın yetkinlik ve yaşam tatmini arasında pozitif yönde düşük düzeyde anlamlı ilişkilere ulaşılmıştır. Ayrıca Çapri, Özkendir, Özkurt ve Karakuş (2012:970) üniversite öğrencileri dahilinde yaptıkları çalışmada da tükenme ve duyarsızlaşmanın yaşam tatmini ile ilişkisinin negatif ve anlamlı olduğu yine yetkinlik ile yaşam tatmini arasındaki ilişkinin de pozitif ve anlamlı olduğu belirlenmiştir. Cazan ve Nastasa (2014:1577) tarafindan üniversite öğrencileri dahilinde yapılan bir çalışmada da tükenmişliğin yaşam tatmini üzerine olumsuz etkileri olduğu bulgusuna ulaşılmıştır. Buna karşın Pınar vd. (2015) tarafından sağlık bilimleri alanlarında eğitim gören üniversite son sınıf öğrencilerinin katılımlarıyla yapılan çalışmada tükenme, duyarsızlaşma ve yetkinlik boyutlarının her üçünün de yaşam tatmini ile negatif yönlü anlamlı ilişkileri olduğu belirlenmiştir. Yine Çapri, Gündüz ve Akbay'ın (2013:35) lise öğrencilerinin katkılarıyla yaptıkları çalışmada da tükenme, duyarsızlaşma ve yetkinlik boyutlarının tamamının yaşam tatmini ile negatif ve anlamlı ilişkileri bulgulanmıştır. Bunlara karşın okul idarecileri kapsamında tükenmişlik ve yaşam tatmini üzerine yapılan bir çalışma ise bu çalışmamızın sonuçları ile tam bir uyum göstermektedir. Karaköse, Kocabaş, Yirci, Esen ve Çelik (2016:1491) tarafından yapılan çalışmada tükenme ve duyarsızlaşma ile yaşam tatmini arasında negatif yönlü bir ilişki söz konusu iken yetkinlik ile yaşam tatmini arasında ise pozitif yönlü bir ilişki belirlenmiştir.

$\mathrm{Bu}$ çalışmanın bulguları ile yetkinlik boyutundaki farklılık için değişik yorumlar yapılabilir. Aslında yetkinlik ile yaşam tatmini arasında olumlu bir ilişki beklenilebilir. Çünkü yukarıda değinildiği gibi benzer sonuçları ortaya koyan araştırmalar olduğu gibi yetkinlik boyutunun önermeleri incelendiğinde mesela "Bana göre iyi bir öğrenciyim" ve "Ders esnasında, yapılan şeylerde etkin olduğumdan eminim" gibi ifadeler yetkinliğin yaşam tatmini ile olumlu yönde ilişkisi olabileceği beklentisini doğurmaktadır. Bu konudaki ilişki daha sonraki çalışmalarda da dikkatle izlenmelidir.

Bu çalışmada kullanılan ve Çapri, Gündüz ve Gökçakan (2011:134) tarafindan Türkçe'ye uyarlanan Maslach Tükenmişlik Envanteri-Öğrenci Formunun faktör yapısı ile ilgili olarak ilgi çekici denilebilecek iki sonucun ortaya çıktığı da belirtilmelidir. Bu çalışmada yetkinlik boyutu güvenirlik katsayısı Cronbach Alpha $(\alpha)=, 591$ çıkmıştır. Yine ölçeğin uyarlama çalışmasında (Çapri vd., 2011:141) aynı boyut için bu katsayı $(\alpha)=.61$ olarak bulunmuştur. Bu değerler bu boyut için kabul edilebilir olmasına karşın zayıf bir güvenirlik katsayısını ifade etmektedir (Akgül ve Çevik, 2005:435-436). İkinci olarak bu çalışmada yapılan keşif amaçlı ve doğrulayıcı faktör analizleri sonucunda bu ölçek içerisinde duyarsızlaşma boyutunda yer alan iki önermenin tükenme boyutuna yüklendikleri gözlemlenmiştir. Bunlar "Okula başladığımdan beri derslere olan ilgim azaldı" ve "Derslerime ilişkin isteğim azaldı" önermeleridir. Anlam açısından bu önermelerin tükenme boyutuna yakın olduğu söylenebilir. Nitekim Lingard (2007:99) tarafından yapılan araştırmada da bu iddiayı destekleyen bir bulgu olduğu görülmektedir. Lingard (2007) çalışmasında, Maslach Tükenmişlik Envanteri-Öğrenci Formu üzerinde yaptığı faktör analizinde 
duyarsızlaşma boyutunda yer alan Türkçe'ye "Derslere ilişkin isteğim azaldı" şeklinde tercüme edilen "I have become less enthusiastic about my studies" önermesi yine bu çalışmada olduğu gibi hem tükenme hem de duyarsızlaşma boyutuna yüklendiği için analizden çıkarılmıştır. Birçok farklı dile uyarlanan ve değişik ülkelerde üzerinde çalışılan Maslach Tükenmişlik Envanteri-Öğrenci Formunun (Faye-Dumanget, Carré, Le Borgne ve Boudoukha, 2017; Portoghese, Leiter, Maslach, Galletta, Porru, D’Aloja vd., 2018; Gumz, Erices, Brähler ve Zenger, 2013; Hu ve Schaufeli, 2009) üçlü faktör yapısı ortaya konmasına rağmen Türkiye'de bu ölçeğin faktör yapısını ortaya koymak adına farklı öğrenci örneklem grupları ile yeni çalışmalar yapılması da değerlendirilebilir.

Üniversite öğrencileri dahilinde yapılan bu çalışmada tükenme ve duyarsızlaşma boyutları ile yaşam tatmini arasında negatif bir ilişki, buna karşın yetkinlik boyutu ile yaşam tatmini arasında pozitif yönlü bir ilişki gözlemlenmiştir. Katılımcı öğrenciler arasındaki tükenme boyutundaki yüksek algı dikkat çekmektedir. Tükenmişliğin daha önce de değinildiği gibi birçok olumsuz sonuçlarının olması ve üniversite öğrencilerinin bir ülkenin geleceğini emanet edeceği nesiller olması açısından bu durum düşündürücüdür. Yine öğrencilerin yaşam tatmini düzeylerinin de düşük çıkması önem arz etmektedir. Gerek tükenme düzeyindeki bu yüksek alg1 gerekse yaşam tatmini düzeyinin olumsuz algılanması üzerinde çalışılabilecek ilginç konular olabilir. Yapılacak boylamsal ve niteliksel araştırmalarla tam olarak nelerin tükenmeye sebebiyet verdiği veya yaşam tatminini nelerin olumsuz etkilediği ortaya konularak, bu doğrultuda çalışmalar yapılabilir. Kısa vadede ise üniversite yönetimleri öğrencilerin yaşadıkları tükenmeyi azaltmaya dönük danışmanlık hizmetleri vb. gibi etkinlikler düzenleyebilirler.

Öğrencilerin çoğunluğunun seçtikleri bölümle ilgili meslekleri önerme konusunda olumsuz düşünmeleri de üzerinde önemle durulması gereken bir konu olarak dikkat çekmektedir. Her ne kadar öğrenciler bir üniversite okuyabilmek adına çok da istemedikleri bölümleri tercih etmiş olabilirler ama bununla birlikte bu oranın yüksekliği öğrencilerin okudukları bölümle ilgili beklentilerinin ne ölçüde karşılan(ama)dığı sorusunu gündeme getirmektedir. Bununla ilgili olarak eğitimin niteliği, müfredat, müfredatın özellikle uygulamadaki yararlılığ , derslerin işlenişi, öğretim üyelerinin tutumları vb. konularının yeniden değerlendirilmesi düşünülebilir. Ayrıca son sınıf öğrencilerinin tükenme düzeylerinin diğer sınıflara göre yüksekliği de bu çalışmanın ortaya koyduğu sonuçlardandır. Bu sonuçta bu sınıfların kısa bir zaman içerisinde işgücü piyasasına dahil olacağı buna karşın 15-24 yaş grupları arasında işsizlik oranının \%25,9 (TÜİK, 2020) gibi yüksek bir oranda olmasının etkisi olabilir. Yaşam tatmininin genel itibarıyla düşük çıkması öğrencilerin sosyo-ekonomik düzeyleri ile ilgili olabilir. Nitekim literatürde yaşam tatmini ile en istikrarlı ilişkiye sahip olan değişkenin gelir olduğu son derece açıktır.

$\mathrm{Bu}$ araştırmanın verileri Coronavirüs nedeniyle başlayan pandemi sürecinin hemen öncesinde elde edilmiştir. Benzer bir araştırmanın bu salgının sona ermesinden sonra yapılması ile iki dönem arasındaki farklılıklar karşılaştırılarak pandemi sürecinin öğrencilerin tükenmişlik ve yaşam tatminlerine etkisinin ne olduğunun ortaya konulması önerilebilir.

Her araştırmanın olduğu gibi bu araştırmanında mutlaka kısıtları bulunmaktadır. Araştırmanın kesitsel olması ve belli bir andaki verilerin elde edilmiş olması bir kısıttır. Sosyal bilimlerde çokça kullanılan nicel veri elde etmeye yönelik araştırma desenlerinin kısıtlılığı, katılımcılardan belli seçenekleri tercih etmelerini istemek, katılımcıların samimiyeti, katılımcının o andaki durumu araştırmanın kısıtları olarak belirtilebilir. Ayrıca araştırmanın zaman, maliyet ve ulaşılabilirlik endişeleriyle sadece bir fakülte ile sınırlandırılması da bir kısıt olarak düşünülebilir.

Bununla birlikte bütün ülkelerin en önemli kaynaklarından olan insan gücünün özellikle üniversite öğrencileri bağlamında tükenmişlik boyutları ve yaşam tatmini gibi önemli olduğu yadsınamayacak konularda genel bir durum ortaya koyan ve belirli demografik değişkenler ve yine bu değişkenler arasındaki ilişkiler açısından faydalı olacağına inanılan bilgiler içeren bu 
araştırmanın literatüre ve uygulamaya katkı sağlayacağı umulmaktadır. Ayrıca geniş sayılabilecek literatür taraması ile de yazına katkısı olacağına inanılan bu çalışmanın yeni çalışmalar için bir hareket noktası olacağına inanılmaktadır.

\section{Araştırma ve Yayın Etiği Beyanı}

Bu çalışma bilimsel araştırma ve yayın etiği kurallarına uygun olarak hazırlanmıştır.

\section{Yazarların Makaleye Katkı Oranları}

Yazarın çalışmaya katkısı \%100'dür.

\section{Çıkar Beyanı}

Yazar açısından ya da üçüncü taraflar açısından çalışmadan kaynaklı çıkar çatışması bulunmamaktadır. 


\section{KAYNAKÇA}

Akgül, A. ve Çevik, O. (2005). İstatistiksel analiz teknikleri (SPSS'de işletme yönetimi uygulamaları). Ankara: Emek Ofset.

Aypay, A. (2011). İlköğretim II. kademe öğrencileri için okul tükenmişliği ölçeği: geçerlik ve güvenirlik çalışması. Kuram ve Uygulamada Eğitim Bilimleri, 11(2), 511-527.

Balogun, J. A., Hoeberlein-Miller, T. M., Schneider, E., \& Katz, J. S. (1996). Academic performance is not a viable determinant of physical therapy students' burnout. Perceptual and Motor Skills, 83(1), 21-22.

Bayrakdar, N. (2016). İslami ilimler fakültesi öğrencilerinde tükenmişlik (Uşak Üniversitesi örneği). Journal of International Social Research, 9(45), 935-946.

Birincioğlu, N., \& Tekin, E. (2018). Mantar yönetim ölçeği geliştirilmesi üzerine bir çalı̧̧ma. Business and Economics Research Journal, 9(1), 169-186.

Cazan, A. M., \& Năstasă, L. E. (2015). Emotional intelligence, satisfaction with life and burnout among university students. Procedia-Social and Behavioral Sciences, 180, 1574-1578.

Cho, E., \& Jeon, S. (2019). The role of empathy and psychological need satisfaction in pharmacy students' burnout and well-being. BMC Medical Education, 19(1), 43.

Chow, H. P. H. (2005). Life satisfaction among university students in a Canadian prairie city: a multivariate analysis. Social Indicators Research, 70(2), 139-150.

Costa, E. F. D. O., Santos, S. A., Santos, A. T. R. D. A., Melo, E. V. D., \& Andrade, T. M. D. (2012). Burnout syndrome and associated factors among medical students: a cross-sectional study. Clinics, 67(6), 573-580.

Çağatay İn, E, Şanlı Kula, K. (2019). Üniversite öğrencilerinin tükenmişlik ve yaşam doyumunun incelenmesi: Kırşehir Ahi Evran Üniversitesi. Uludağ Üniversitesi Ĕgitim Fakültesi Dergisi, 32 (2), 403-442.

Çapri, B., Gündüz, B. ve Gökçakan, Z. (2011). Maslach tükenmişlik envanteri-öğrenci formu (MTE-ÖF)' nin Türkçe'ye uyarlaması: geçerlik ve güvenirlik çalışması. Çukurova Üniversitesi Eğitim Fakültesi Dergisi, 1 (40), 134 147.

Çapri, B., Özkendir, O. M., Özkurt, B., \& Karakuş, F. (2012). General self-efficacy beliefs, life satisfaction and burnout of university students. Procedia-Social and Behavioral Sciences, 47, 968-973.

Çapri, B., Gündüz, B., \& Akbay, S. E. (2013). The study of relations between life satisfaction, burnout, work engagement and hopelessness of high school students. International Education Studies, 6(11), 35-46.

Demerouti, E., Bakker A.B., Nachreiner F. \& Schaufeli, W.B. (2000). A model of burnout and life satisfaction amongst nurses. Journal of Advanced Nursing, 32(2), 454-464.

Demir, Ü. (2020). Kardeş durumu ve mutluluk: Çanakkale'de lise öğrencileri üzerine bir araştırma. Manas Sosyal Araştırmalar Dergisi, 9(2), 798-808.

Demir, Ö., \& Taşkıran, G. (2018). İ̈BF mezun adaylarının iş bulma ümitlerini etkileyen faktörler üzerine nicel bir araştırma. Çalışma İlişkileri Dergisi, 9(1), 42-57.

Demirel, O. N., Yılmaz, Y., \& Üngüren, E. (2015). Meslek yüksekokulu öğrencilerinin tükenmiş̧lik düzeyleri üzerine bir araştırma. EKEV Akademi Dergisi, 19(62), 173-184.

Diener, E. (2006). Guidelines for national indicators of subjective well-being and ill-being, Applied Research in Quality of Life, 1,151-157.

Diener, E., Diener, M. \& Diener, C. (1995). Factors predicting the subjective well-being of nations. Journal of Personality and Social Psychology, 69 (5), 851 -864.

Diener, E. D., Emmons, R. A., Larsen, R. J., \& Griffin, S. (1985). The satisfaction with life scale. Journal of Personality Assessment, 49(1), 71-75.

Diener, E., Oishi, S., \& Lucas, R. E. (2003). Personality, culture, and subjective well-being: emotional and cognitive evaluations of life. Annual Review of Psychology, 54(1), 403-425.

Doğan, İ. (2015). Farklı veri yapısı ve örneklem büyüklüklerinde yapısal eşitlik modellerinin geçerliği ve güvenirliğinin değerlendirilmesi. Doktora tezi. Eskişehir Osmangazi Üniversitesi, Eskişehir.

Dyrbye, L. N., Thomas, M. R., Massie, F. S., Power, D. V., Eacker, A., Harper, et al. (2008). Burnout and suicidal ideation among US medical students. Annals of Internal Medicine, 149(5), 334-341. 
Dyrbye, L. N., West, C. P., Satele, D., Boone, S., Tan, L., Sloan, J., Shanafelt, T. D. (2014). Burnout among U.S. medical students, residents, and early career physicians relative to the general U.S. population, Academic Medicine, 89 (3), 443-451.

Eren A.S. (2018). Anketlerin veri girişlerinin kolay bir şekilde yapılmasını sağlayan bilgisayar tabanlı bir yöntemin tanitımı. Social Mentality and Researcher Thinkers Journal. 4(8), 76-83.

Faye-Dumanget, C., Carré, J., Le Borgne, M., \& Boudoukha, P. A. H. (2017). French validation of the Maslach Burnout Inventory-Student Survey (MBI-SS). Journal of Evaluation in Clinical Practice, 23(6), 1247-1251.

Freudenberger, H. J. (1989). An overview of burnout: past, present and future concerns. İçinde D.T. Wessells, A. H. Kutscher, I. B. Seeland IB, F. E. Selder, D. J. Cherico ve E. J. Clark (Eds.), Professional Burnout in Medicine and Helping Professions, (ss.1-10). New York, Routledge.

George, D. \& Mallery, P. (2016). IBM SPSS statistics 23 step by step a simple guide and reference. New York: Routledge.

Gorji, A. M. H., Teimuri, F., Gorji, M. A. H., \& Gorji, R. H. (2015). Job burnout and life satisfaction among nurses and midwives of medical institutions in northern Iran: a cross-sectional study. Tropical Journal of Medical Research, 18(1), 34-37.

Gökalp, M., \& Topal, T. (2019). Investigation of life satisfaction of university students according to various variables. The Turkish Online Journal of Educational Technology, 2, 191-204.

Gumz, A., Erices, R., Brähler, E., \& Zenger, M. (2013). Factorial structure and psychometric criteria of the German translation of the Maslach burnout inventory-student version by Schaufeli et al. (MBI-SS). Psychotherapie, Psychosomatik, Medizinische Psychologie, 63(2), 77-84.

Gündoğar, D., Gül, S. S., Uskun, E. Demirci, S. \& Keçeci, D. (2007). Üniversite öğrencilerinde yaşam doyumunu yordayan etkenlerin incelenmesi. Klinik Psikiyatri, 10, 14-27.

Gündüz, B., Çapri, B. \& Gökçakan, Z. (2012). Üniversite öğrencilerinin tükenmişlik düzeylerinin incelenmesi. Dicle Üniversitesi Ziya Gökalp Eğitim Fakültesi Dergisi, 19, 38-55.

Güney, S., Kalafat, T., \& Boysan, M. (2010). Dimensions of mental health: life satisfaction, anxiety and depression: a preventive mental health study in Ankara University students population. Procedia-Social and Behavioral Sciences, 2(2), 1210-1213.

Hakanen, J. J., \& Schaufeli, W. B. (2012). Do burnout and work engagement predict depressive symptoms and life satisfaction? A three-wave seven-year prospective study. Journal of Affective Disorders, 141(2-3), 415-424.

Hernesniemi, E., Räty, H., Kasanen, K., Cheng, X., Hong, J., \& Kuittinen, M. (2017). Burnout among Finnish and Chinese university students. Scandinavian Journal of Psychology, 58 (5), 400-408.

Hu, Q., \& Schaufeli, W. B. (2009). The factorial validity of the Maslach burnout inventory-student survey in China. Psychological Reports, 105(2), 394-408.

Karakose, T., Kocabas, I., Yirci, R., Esen, C., \& Celik, M. (2016). Exploring the relationship between school principals' burnout situation and life satisfaction. Universal Journal of Educational Research, 4(6), 1488-1494.

Kiuru, N., Aunola, K., Nurmi, J. E., Leskinen, E., \& Salmela-Aro, K. (2008). Peer group influence and selection in adolescents' school burnout: a longitudinal study. Merrill-Palmer Quarterly (1982-), 23-55.

Köker, S. (1991). Normal ve sorunlu ergenlerin yaşam doyumu düzeyinin karşılaştırılması. Yüksek Lisans Tezi, Ankara Üniversitesi Sosyal Bilimler Enstitüsü, Ankara.

Law, D. (2007) Exhaustion in university students and the effect of coursework involvement. Journal of American College Health, 55(4), 239-245.

Lingard, H. (2007). Conflict between paid work and study: does it impact upon students' burnout and satisfaction with university life? Journal for Education in the Built Environment, 2(1), 90-109.

Maslach, C. \& Jackson, S. E. (1981). The measurement of experienced burnout. Journal of Occupational Behavior, 2, 99-113.

Maslach, C., Schaufeli, W.B. \& Leiter, M.P. (2001). Job burnout. Annual Review of Psychology, 52, 397-422.

Milevsky, A., Schlechter, M., Netter, S., \& Keehn, D. (2007). Maternal and paternal parenting styles in adolescents: associations with self-esteem, depression and life-satisfaction. Journal of Child and Family Studies, 16(1), 39-47.

Møller, V. (1996). Life satisfaction and expectations for the future in a sample of university students: a research note. South African Journal of Sociology, 27(1), 16-26. 
Ören, N., \& Türkoğlu, H. (2006). Öğretmen adaylarında tükenmişlik. Muğla Üniversitesi Sosyal Bilimler Enstitüsü Dergisi, (16).

Özbay, Y., Palancı, M., Kandemir, M., \& Çakır, O. (2012). Üniversite öğrencilerinin öznel iyi oluşlarının duygusal düzenleme, mizah, sosyal öz-yeterlik ve başaçıkma davranışları ile yordanması. Journal of Turkish Educational Sciences, 10 (2), 325-345.

Öztürk, M. \&Ünal, V. (2019). Temel insani değerler ile yaşam doyumu arasındaki ilişki: Sivas Cumhuriyet Üniversitesi örneği. Hacettepe Üniversitesi Edebiyat Fakültesi Dergisi, 36(1), 61-74.

Pavot, W. \& Diener, E. (1993). Review of the satisfaction with life scale. Psychological Assessment, 5(2). 164-172.

Pérez-Fuentes, M. D. C., Molero Jurado, M. D. M., Gázquez Linares, J. J., Oropesa Ruiz, N. F., Simón Márquez, M. D. M., \& Saracostti, M. (2019). Parenting practices, life satisfaction, and the role of self-esteem in adolescents. International Journal of Environmental Research and Public Health, 16(20), 4045.

Pınar, Ş. E., Bilgiç, D., Demirel, G., Akyüz, M. B., Karatepe, C., \& Sevim, D. (2015). Sağlık alanlarında okuyan üniversite öğrencilerinin tükenmişlik ve yaşam doyumları arasındaki ilişki. TAF Preventive Medicine Bulletin, 14(4).

Portoghese I., Leiter M.P., Maslach C., Galletta M., Porru F., D’Aloja E., et al. (2018). Measuring burnout among university students: factorial validity, invariance, and latent profiles of the Italian version of the Maslach burnout inventory student survey (MBI-SS). Frontiers in Psychology. 9, 1-9.

Robins, T. G., Roberts, R. M., \& Sarris, A. (2018). The role of student burnout in predicting future burnout: exploring the transition from university to the workplace. Higher Education Research \& Development, 37(1), 115-130.

Salanova, M., Schaufeli, W., Martínez, I., \& Bresó, E. (2010). How obstacles and facilitators predict academic performance: the mediating role of study burnout and engagement. Anxiety, Stress \& Coping, 23(1), 53-70.

Salmela-Aro, K., Kiuru, N., Leskinen, E., \& Nurmi, J. E. (2009). School burnout inventory (SBI) reliability and validity. European Journal of Psychological Assessment, 25(1), 48-57.

Schaufeli, W.B. \& Buunk, B.P. (2003): Burnout: an overview of 25 years of research and theorizing. İçinde M. Schabracq, J.A.M. Winnubst \& C.L. Cooper (Eds.), The handbook of work \& health psychology (İkinci Bask1; ss. 383425). Chichester: Wiley.

Schaufeli, W.B., Leiter, M.P. \& Maslach, C. (2009). Burnout: 35 years of research and practice. Career Development International, 14, 204-220.

Schaufeli, W.B. \& Taris, T.W. (2005). The conceptualization and measurement of burnout: common ground and worlds apart. Work \& Stress, 19 (3), 256-262.

Schaufeli, W. B., Martinez, I. M., Pinto, A. M., Salanova, M., \& Bakker, A. B. (2002). Burnout and engagement in university students: a cross-national study. Journal of Cross-Cultural Psychology, 33(5), 464-481.

Seçer, B., \& Yazıcı, M. O. (2018). Üniversite öğrencilerinde iş umudu ve tükenmişlik ilişkisi. Çalışma İlişkileri Dergisi, 9 (2), 48-60.

Seçer, İ. (2015). Üniversite öğrencilerinde okul tükenmişliği ile psikolojik uyumsuzluk arasındaki ilişkinin incelenmesi. Atatürk Üniversitesi Sosyal Bilimler Enstitüsü Dergisi, 19 (1), 81-99.

Seçer, İ., Halmatov, S., Veyis, F., \& Ateş, B. (2013). Okul tükenmişlik ölçeğinin Türk kültürüne uyarlanması: güvenirlik ve geçerlik çalışması. Turkish Journal of Education, 2 (2), 16-24.

Sevencan, F., Uzun, N., Yücel, E. H., Şener, A., Yılmaz, A. E., \& Üner, S. (2011). Hacettepe üniversitesi tıp fakültesi dönem v1 öğrencilerinde tükenmişlik düzeyi ve etkileyen faktörler. Hacettepe Tip Dergisi, 42(1), 42-8.

Shankland, R., Kotsou, I., Vallet, F., Bouteyre, E., Dantzer, C., \& Leys, C. (2019). Burnout in university students: the mediating role of sense of coherence on the relationship between daily hassles and burnout. Higher Education, 78(1), 91-113.

Tansel, B. (2015). Üniversite öğrencilerinin tükenmişlik düzeylerinin incelenmesi. Çukurova Üniversitesi Eğitim Fakültesi Dergisi, 44(2), 241-268.

Tsitsas, G., Nanopoulos, P., \& Paschali, A. (2019). Life satisfaction, and anxiety levels among university students. Creative Education, 10, 947-961.

Tuzgöl Dost, M. (2010). Güney Afrika ve Türkiye'deki üniversite öğrencilerinin bazı değişkenlere göre öznel iyi oluş ve yaşam doyumlarının incelenmesi. Ĕ̌itim ve Bilim, 35(158), 75-89.

TÜİK (2020, Ekim). İşǚcü istatistikleri [Basın bülteni]. Erişim adresi https://data.tuik.gov.tr/tr/displaybulletin/?bulletin=isgucu-istatistikleri-temmuz-2020-33791, Erişim tarihi: 01.12.2020. 
Tümkaya, S., \& Çavuşoğlu, İ. (2010). Sınıf öğretmenliği son sınıf öğretmen adaylarının tükenmişlik düzeylerinin incelenmesi. Çukurova Üniversitesi Sosyal Bilimler Enstitüsü Dergisi, 19(2), 468-481.

Wachholtz A. \& Rogoff, M. (2013). The relationship between spirituality and burnout among medical students. Journal of Contemporary Medical Education, 1(2), 83-91.

Walburg, V. (2014). Burnout among high school students: a literature review. Children and Youth Services Review, 42, 28-33.

Wang, Q., Wang, L., Shi, M., Li, X., Liu, R., Liu, J.et al. (2019). Empathy, burnout, life satisfaction, correlations and associated socio-demographic factors among Chinese undergraduate medical students: an exploratory cross-sectional study. BMC Medical Education, 19(1), 341.

Yaşlığlu, M. M. (2017). Sosyal bilimlerde faktör analizi ve geçerlilik: Keşfedici ve doğrulayıcı faktör analizlerinin kullanılması. İstanbul Üniversitesi Işsletme Fakültesi Dergisi, 46, 74-85. 


\section{Extended Summary}

\section{Burnout and Life Satisfaction Amongst University Students: A Study on KSU Students}

It can be said that achieving the subjective well-being of the society is closely related to the fact that all the groups that make up it are as far away from problems as possible. In this context, the issue of burnout, which should be considered and can be said to be an important problem for almost all segments of the society, draws attention. In addition, determining the life satisfaction levels used in determining the subjective well-being of individuals is also important in revealing the general happiness level of the society. Although there are many studies in the literature on burnout and subjective well-being, it can be claimed that there is not enough research on these issues in the local literature about a group that can be claimed to be important for the society namely university students. In this context, the main purpose of this study is to determine the burnout and life satisfaction levels of the university students and to reveal the relationships between them. It can be claimed that this group will form the future of the society to some extent, so it is important to reveal the perceived the current state of burnout and subjective well-being of this group. In addition, it is thought that this study, which is based on a wide literature review on burnout and life satisfaction, will contribute to the literature in terms of both theoretical and practical dimensions.

Although students' burnout started to attract attention in the literature, especially since the 1980s, (Balogun, Hoeberlein-Miller, Schneider ve Katz, 1996:21; Schaufeli, Martinez, Pinto, Salanova ve Bakker, 2002:464; Kiuru, Aunola, Nurmi, Leskinen ve Salmela-Aro, 2008:25; Salanova, Schaufeli, Martínez ve Bresó, 2010:54) it is seen that the main interest in the subject in our country started after the 2010s (Çapri, Gündüz ve Gökçakan, 2011:134; Aypay, 2011:511; Seçer, Halmatov, Veyis ve Ateş, 2013:16). Although students are not employed and do not undertake a special task, when considered in a psychological context, the basic activities of studentship can be considered as a job. Because being a student requires structured and compulsory basic activities such as attending classes and doing homework, as well as achieving specified goals such as being successful in exams and obtaining a certain diploma. Therefore, burnout can be found implicitly or explicitly among students (Schaufeli, Martinez, Pinto, Salanova ve Bakker, 2002:464; Schaufeli ve Taris, 2005:260; Salmela-Aro, Kiuru, Leskinen ve Nurmi, 2009:48).

Burnout is a three-dimensional syndrome, and its main dimension is increased emotional exhaustion. Employees who feel that their emotional resources have been exhausted start to think that they have nothing left to give to their jobs psychologically. The second dimension is the skeptical attitudes developed towards the people they serve. This attitude is associated with emotional exhaustion. This perception, which is somewhat inhuman, gives rise to the idea that service receivers deserve what happened to them. The third dimension is that the person evaluates himself negatively about his job and the service they provide, that is, feeling unhappy about himself and not finding his job performance satisfactory (Maslach ve Jackson, 1981:99).

Life satisfaction refers to individuals' judgments about their lives in the context of their own criteria. People evaluate to what extent these standards are met by comparing their perceived living conditions with the standards they set themselves. If their perceived living standards are above the standards they set, they express that they have high life satisfaction. Therefore, life satisfaction is the cognitive judgment of each individual about his or her own living standards (Pavot ve Diener, 1993:164). 
In the literature review conducted on the subject, it was observed that burnout and depersonalization were negatively correlated with life satisfaction, and the competence dimension had a positive relationship with life satisfaction (Çağatay İn ve Şanlı Kula, 2019:411; Çapri, Özkendir, Özkurt and Karakuş, 2012:970; Karaköse, Kocabaş, Yirci, Esen ve Çelik, 2016:1491). However, in some studies, it was determined that all dimensions have a negative relationship with life satisfaction (Pınar vd., 2015:284; Çapri, Gündüz ve Akbay, 2013:41). In studies on the relationship between burnout and life satisfaction generally negative relationship was found. In other words, perceived burnout negatively affects life satisfaction (Cho ve Jeon, 2019:6-8; Wang, Wang, Shi, Li, Liu, Liu et al., 2019:8; Güney, Kalafat ve Boysan, 2010:1210; Wachholtz and Rogoff, 2013:86). When these results are evaluated, it can be expected that the perceived burnout of the students will negatively affect the general life satisfaction of the individual. Therefore, the main hypothesis of the study can be summarized as that there is a negative relationship between participant students' perceived burnout, depersonalization and competence levels and life satisfaction. In addition, determining the relationships between some of the demographic characteristics of the participant students and the basic variables such as burnout, depersonalization, competence and life satisfaction are among the secondary purposes of this study. The universe of the study consists of 4435 students enrolled in different departments of the Faculty of Economics and Administrative Sciences of Kahramanmaraş Sütçü İmam University in the 2019/2020 academic year. For the research, permission was obtained from the Social and Human Sciences Ethics Committee of Kahramanmaraş Sütçü İmam University with a letter dated 03/10/2019 and numbered E.40523. In the sample selection, convenience sampling method was preferred.

Maslach Burnout Inventory-Student Form (Schaufeli et al., 2002) and Life Satisfaction scales (Diener et al., 1985) were used to collect data in the study. As a result, 475 questionnaires were answered. The data were analyzed using the SPSS program. The data were tested for normality test and nonparametric tests were used to analyse because there was no normal distribution. Frequency distribution, reliability, exploratory factor analysis, confirmatory factor analysis, Mann Whitney U, Kruskal Wallis, correlation and Structural Equation Model tests were applied to the obtained data.

In this study conducted with university students, a negative relationship was observed between the dimensions of burnout and depersonalization and life satisfaction, whereas a positive relationship was observed between the competence dimension and life satisfaction. The high perception of the burnout dimension among the participating students draws attention. This situation is thought-provoking in that burnout has many negative consequences as mentioned before and there are generations that university students will entrust the future of a country. It is also important that the life satisfaction levels of the students were low. In addition, the higher burnout levels of senior students compared to other grades is one of the results of this study. The low life satisfaction in general may be related to the socio-economic level of the students.

It is a constraint that the research is cross-sectional and that data at a particular time has been obtained. The limitations of research designs aimed at obtaining quantitative data widely used in social sciences, asking participants to choose certain options, the sincerity of the participants, and the current situation of the participant can be stated as the limitations of the research. In addition, limiting the research to only one faculty due to time, cost and accessibility concerns can be considered as a constraint. In addition, it is believed that this study to contribute to the literature with a large literature review as well and it may be a starting point for new studies. 
Optimum Journal of Economics and Management Sciences, Vo1. 8, No. 2- https://dergipark.org.tr/tr/pub/optimum Macit - Burnout and Life Satisfaction Amongst University Students: A Study on KSU Students 